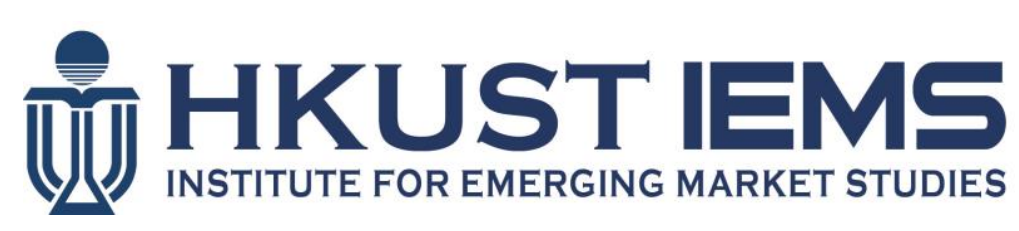

\title{
Asymmetric Information and Middleman Margins: An Experiment with Indian Potato Farmers
}

Sandip MITRA, Dilip MOOKHERJEE, Maximo TORERO, Sujata VISARIA

HKUST IEMS Working Paper No. 2015-29

August 2015

HKUST IEMS working papers are distributed for discussion and comment purposes. The views expressed in these papers are those of the authors and do not necessarily represent the views of HKUST IEMS.

More HKUST IEMS working papers are available at: http://iems.ust.hk/WP 


\title{
Asymmetric Information and Middleman Margins: An Experiment with Indian Potato Farmers
}

\author{
Sandip MITRA, Dilip MOOKHERJEE, Maximo TORERO, Sujata VISARIA
}

HKUST IEMS Working Paper No. 2015-29

August 2015

\begin{abstract}
In the Indian state of West Bengal, potato farmers sell to local middlemen because they lack direct access to wholesale markets. In high-frequency farmer marketing surveys we find that farmers are poorly informed about wholesale and retail prices, and there is a large gap between wholesale and farmgate prices. To test alternative models of farmer-middlemen trades, we conduct a field experiment providing farmers in randomly chosen villages with market price information. Information provision had negligible average effects on farmgate sales and revenues, but increased pass-through from wholesale to farmgate prices. The results are inconsistent with models of risk-sharing via contracts between middlemen and farmers. They are consistent with a model of ex post bargaining and sequential price competition between a cartel of village middlemen and a cartel of external middlemen.
\end{abstract}

\section{Authors' contact information}

Sandip Mitra

Sampling and Oial Statistics Unit

Indian Statistical Institute

203 B.T. Road, Kolkata 700108

India

E: sandip@isical.ac.in

Click here to enter text.

Dilip Mookherjee

Department of Economics

Boston University

270 Bay State Road, Boston, MA 02215

USA

E: dilipm@bu.edu

Maximo Torero

International Food Policy Research Institute 
Sujata Visaria

Department of Economics

Hong Kong University of Science and Technology

Clear Water Bay, Kowloon

Hong Kong

E: svisaria@ust.hk 


\title{
Asymmetric Information and Middleman Margins:
}

\author{
An Experiment with Indian Potato Farmers*
}

\author{
Sandip Mitrał Dilip Mookherjee; Maximo Torero ${ }^{\S}$ and Sujata Visaria
}

July 30, 2015

\begin{abstract}
In the Indian state of West Bengal, potato farmers sell to local middlemen because they lack direct access to wholesale markets. In high-frequency farmer marketing surveys we find that farmers are poorly informed about wholesale and retail prices, and there is a large gap between wholesale and farmgate prices. To test alternative models of farmer-middlemen trades, we conduct a field experiment providing farmers in randomly chosen villages
\end{abstract}

*The data collection for this project was funded by grants from the Hong Kong Research Grants Council, the International Food Policy Research Institute (IFPRI) in Washington DC, the International Growth Centre (IGC) at the London School of Economics and USAID's Development Innovation Ventures (DIV) program. For their helpful comments and suggestions on different versions, we are grateful to Abhijit Banerjee, Francesco Decarolis, Jordi Jamandreu, Dan Keniston, Asim Khwaja, Kaivan Munshi, Rohini Pande, Marc Rysman, Chris Udry, and participants at several seminars and conferences. This project has benefitted from the research assistance of Clarence Lee, Khushabu Kasabwala, Prathap Kasina, Owen McCarthy, Sanyam Parikh, Moumita Poddar, Sunil Shoo and Ricci Yeung. All errors are our own.

${ }^{\dagger}$ Indian Statistical Institute, Kolkata

${ }^{\ddagger}$ Boston University

$\S$ International Food Policy Research Institute

『Hong Kong University of Science and Technology 
with market price information. Information provision had negligible average effects on farmgate sales and revenues, but increased pass-through from wholesale to farmgate prices. The results are inconsistent with models of risk-sharing via contracts between middlemen and farmers. They are consistent with a model of ex post bargaining and sequential price competition between a cartel of village middlemen and a cartel of external middlemen. (JEL Codes: O120, L140) 


\section{Introduction}

It is commonly believed that middlemen margins are a large component of agricultural value chains in developing countries. ${ }^{1}$ However, there is little evidence on the magnitude of middlemen margins and their determinants. Our understanding of the trading mechanisms between farmers and traders in LDCs is also limited. ${ }^{2}$ Do farmers and traders engage in risk-sharing contracts, or do they bargain ex post only at the time of sale? What are farmers' outside options or bargaining power? Do they have less information than traders about price movements in downstream markets, and does this asymmetry of information worsen their bargaining position? A better understanding of these issues can tell us what prevents the gains from trade from "trickling down" to the ultimate producers.

In this paper we examine these questions in the context of the supply chain for potatoes, which are a high-value cash crop in the Indian state of West Bengal. More than $90 \%$ of the farmers in our study area sell potatoes to village middlemen, who aggregate purchases and then re-sell them at wholesale markets to buyers from distant cities or neighbouring states. The remaining farmers sell them in neighboring local markets to other middlemen, who resell them in neighboring wholesale markets. Not only do farmers lack direct access to wholesale markets, they also do not have independent information about the wholesale market prices at which the middlemen resell their produce. Gaps between the resale prices and

\footnotetext{
${ }^{1}$ For example, Morisset (1998) conjectures that trading companies may have caused the large and increasing gaps between world commodity prices and consumer prices observed from the mid1970s to the mid-1990s. Other research argues that increases in export prices do not translate into commensurate increases in producer prices for cash crops because middlemen dissipate the gains from trade (Fafchamps and Hill 2008, McMillan, Rodrik, and Welch 2002).

${ }^{2}$ Recent theoretical contributions include Antras and Costinot (2010), Antras and Costinot (2011), Bardhan, Mookherjee, and Tsumagari (2013) and Chau, Goto, and Kanbur (2009).
} 
farmgate prices were large. In the year of our study, farmgate prices (received from middlemen) were on average only 53 percent of the (gross) wholesale prices (at which middlemen resold the potatoes). Our back-of-the-envelope calculation suggests that middlemen earned (net of transport and storage costs) $28-38 \%$ of the wholesale price, and $64-83 \%$ of the farmgate price per kilogram of potatoes traded. Between 64 and 81 percent of retail price variations passed through to wholesale prices in different years, but only a statistically insignificant 2 percent passed through to farmgate prices in 2008.

Clearly, to understand why potato middlemen earn large margins we need to understand the trading mechanism with farmers. This is difficult to gauge directly from farmer surveys. Our surveys show that traders and farmers often engage in repeat transactions. Yet, only a minority of farmers reported being bound by an advance contractual arrangement. The majority described a process of ex post bargaining where village middlemen make daily price offers, to which farmers respond by choosing to sell rightaway, holding out for a future sale, or transporting to a neighbouring small market (called a haat) to sell to a different middleman.

These trading arrangements are in sharp contrast to those prevailing in a number of other Indian states, and other developing country contexts. In states such as Madhya Pradesh, Maharashtra and Kerala, farmers sell directly to wholesale or retail markets, sometimes via auctions conducted by government regulators (Goyal 2010, Fafchamps and Minten 2012, Jensen 2007). ${ }^{3}$ In these contexts, farmers engage in spatial arbitrage across different wholesale or retail markets, and access to market price information enhances their ability to do so. ${ }^{4}$ Blouin and Machiavello

\footnotetext{
${ }^{3}$ Aker (2010) also examined the effect of mobile phones on price dispersion, but studied grain traders in Niger instead of farmers.

${ }^{4}$ The marketing arrangements differ across Indian states partly as a result of differences in government marketing regulations. Cohen (2013) provides a detailed description of agricultural
} 
(2013), Machiavello and Morjaria (2015) and Saenger, Torero, and Qaim (2014) study contexts where farmers enter into advance contracts with middlemen but also have the option to sell directly in a spot market; the resulting moral hazard problem limits the extent of risk-sharing achieved. However a number of other developing country settings (such as coffee markets in Kenya Fafchamps and Hill 2008 and cashew markets in Mozambique McMillan, Rodrik, and Welch 2002) are similar to West Bengal potato markets in that most farmers sell to local middlemen, and there is low pass-through of market prices to farmgate prices. There is insufficient evidence in the literature about the prevalence or nature of vertical contracts between farmers and middlemen in such contexts.

Theoretical analyses of vertical relationships in supply chains usually consist of contracting models involving risk-sharing (Hart 1983, Ligon, Thomas, and Worrall 2002, Machiavello (2010)) or spot market models of oligopolistic competition among middlemen either with or without search frictions. ${ }^{5}$ We are not aware of any attempts to discriminate between these different models. A major goal of this paper is to use empirical evidence from West Bengal potato supply chains to do so. A related goal is to study the role of policy measures that attempt to reduce information asymmetries by providing market price information to farmers.

The theoretical models we consider are the following: (i) contracting with full commitment but with asymmetric price information; (ii) contracting with limited commitment due to ex post moral hazard; (iii) spot market transactions involving simultaneous move models of oligopolistic collusion or price competition among middlemen, with or without search frictions; and (iv) sequential price competition

marketing regulations and practice in West Bengal.

${ }^{5}$ For example, see Antras and Costinot (2010), Antras and Costinot (2011), Chau, Goto, and Kanbur (2009) for the former, and Atkin and Donaldson (2014), Gopinath and Itskhoki (2010), Weyl and Fabinger (2013), Villas-Boas (2007) for the latter. 
between a local middleman (cartel) and a market middleman (cartel). These models generate different predictions about the impact of price information provision to farmers. Models of type (i) predict that information provision would remove the screening distortion caused by information asymmetry and therefore increase the quantity transacted, especially in states of the world with low wholesale prices. Models of types (ii) and (iii) predict no effect: as long as farmers lack direct access to wholesale markets, information provision does not change their outside option (i.e., their payoff if they do not sell to any of the middlemen), or how middlemen optimally respond to each other's price offers.

While models (i)-(iii) are standard, model (iv) is novel. As we show, it predicts either no effect of information provision, or increased pass-through to farmgate prices with a zero average effect, implying that farmers sell less (more) in low (high) wholesale-price-states. This is because the local middleman who moves first is aware that his price offer can communicate information about the price offer that the market middlemen would make subsequently if the farmer were to reject the local middleman's offer. The model has a continuum of equilibria, varying in the extent of information revealed by the first offer. There always exists a completely revealing equilibrium, where the local middleman's price offer varies monotonically with the wholesale market price and thus removes the information asymmetry. If this is the realized equilibrium, then external information provision will have no effect. There also exist a set of equilibria with varying degrees of pooling, which can be affected by the external provision of information. Specifically, any equilibrium with a "high" degree of pooling will cease to exist, because the information provision will cause farmers to revise their beliefs downwards in low (resp. upwards in high) price-states, resulting in lower (resp. higher) farmgate prices and sales. In contrast to the other models, model (iv) therefore predicts that farmgate sales and revenues 
will shrink when market prices are unexpectedly low.

In 2008 we conducted a field experiment in 72 villages designed to test these predictions. Farmers in 48 randomly chosen villages in two leading potato-growing districts of West Bengal were given daily information about the prevailing potato prices in neighboring wholesale and retail markets. In another 24 control villages, no information was provided. Simultaneously we surveyed a random sample of potato farmers in all villages, to collect high-frequency data on their cultivation, harvest, sales and related revenues and costs. Our main finding is that the predictions are consistent only with model (iv). Holding constant both unobservable and observable time-invariant characteristics of the local wholesale potato market (mandi), and controlling for the farmer's landholding and the variety and quality of potatoes sold, we find no evidence of significant average treatment effects on farmgate sales or revenues. The point estimates of the effects of information provision are negative for both quantity and revenues, when mandi-specific time-invariant factors are held constant. However, farmers were affected differently depending on whether they were located in areas where the realised mandi price was unexpectedly high or low. The information intervention significantly lowered (raised) the quantity sold and revenue earned by farmers whose potatoes were resold in mandis with unexpectedly low (high) prices in 2008. This is consistent only with model (iv). Additional predictions of this model are also confirmed: controlling for the wholesale price, the farmgate price was lower on average than the price the farmer would receive at the market. Also, the farmer is more likely to reject the first offer and sell outside the village when the mandi price is higher. 


\section{The Context: Potato Production and Sales}

Potatoes generate the highest value-added per acre among cash crops in West Bengal (Bardhan and Mookherjee 2011), and have the highest acreage among all winter crops in the two districts in our study, Hugli and West Medinipur (Maitra et al. 2015). They are planted between October and December, and harvested between January and March. They can be sold immediately at the time of harvest, or, if placed in home stores they can be sold up to two or three months later. Alternatively they can be placed in cold stores, and then sold any time until November, when the new planting season begins. Note however that cold storage technicalities and government regulations require that cold stores be emptied at the end of November, so that they cannot be carried over from one year to the next.

\subsection{Farmer-Trader Transactions and Market Structure}

The local supply chain is organized as in Figure 1. Our baseline survey shows that in 2006 (that is, before our intervention began), sample farmers sold 98 percent of their produce to local intermediaries or village traders. These village traders aggregate purchases from local farmers, transport them to wholesale markets (called mandis) and then sell to traders in city markets or in neighboring states.Village traders are usually residents of the same or a neighbouring village. ${ }^{6}$

Potatoes from Hugli district are usually sold ultimately in Kolkata retail markets, and in states in Eastern and Northeastern India such as Assam, Bihar and Jharkhand. Potatoes from West Medinipur district are sold in the Bhubaneswar

\footnotetext{
${ }^{6}$ Besides buying potatoes, they trade in other seasonal produce and often sell agricultural inputs and provide credit; most of them have a shop in the village. Thus farmers and traders interact face-to-face at a high frequency, making it unlikely that either farmers or village traders incur large search costs.
} 
market in neighboring Orissa, or in the southern state of Andhra Pradesh. As we will discuss in Section 5.1, price movements in the city retail markets explain much of the movement in local mandi prices that we observe.

Village middlemen usually buy from a network of farmers who have a track record of selling potatoes of uniform quality and not cheating them by mixing potatoes of different grades in their sacks, or placing a smaller quantity in the sack. In 2007, sample farmers sold nearly 72 percent of their potatoes to buyers whom they had been selling to for a year or more, and 32 percent to buyers whom they had been selling to for two years or more. This high incidence of repeat transactions among the same partners raises the possibility (but does not guarantee the existence) of contractual arrangements. For instance, in 2007 sample farmers sold only 21 percent of their potatoes to buyers whom they had an outstanding loan from.

Farmers also told us that they were not bound to sell to the trader who had provided them inputs or credit, but were free to sell to someone else and to use the proceeds to repay the loan. Table 1 uses data from surveys of purchasing middlemen in the same set of 72 villages, to throw more light on the nature of the trading mechanism. One third or less of the middlemen reported having any prior contractual agreement with farmers they purchased from. Of these, less than 15\% reported an explicit contractual understanding about the price, and $17 \%$ about the quantity to be transacted. Less than $45 \%$ (of those reporting a contractual relationship) reported an implicit understanding about the price. Hence less than $20 \%$ of all middlemen reported any explicit or implicit advance agreement concerning the price. Most of them also reported that farmers were free to sell to others.

There are on average 10 traders operating in any village, and in informal in- 
terviews farmers also report being free to sell to any of these. Direct sales to large buyers from distant markets are extremely rare, most likely because these buyers think it is "not worth their while" to negotiate small trade volumes with so many different farmers whom they do not know personally, and therefore cannot trust to provide reliable quality. Instead, one alternative to selling to a particular village trader is to sell to another village trader. However, village traders admit to discussing price offers with each other, and checking with farmers the prices at which they recently sold to others, so it quite possible that they tacitly collude on prices within the village. It is less likely that they collude with traders from other villages or at haats, since they meet them less frequently. When responding to a price offer from a village trader on any given day, farmers perceive their main outside option as taking their potatoes to the haat and selling to a trader in that market, or waiting to sell later in the year. ${ }^{7}$ Our model of ex post bargaining with sequential competition between a village trader and a trader at a haat builds on these institutional details.

\subsection{Price Information of Farmers}

Since transactions between the traders and the buyers from distant markets whom they sell to are often bilateral, information about the trader's resale price at the mandi is not in the public domain. Instead, Table C1 (Panel E, column 1) shows that before our intervention began, 71 percent of sample farmers reported they learnt about mandi prices from the village trader, and 46 percent said the trader was their only source of information. About 13 percent reported asking friends and neighbours, and 6 percent gathered information from the media, although media

\footnotetext{
${ }^{7}$ In 2006, sample farmers sold only 1 percent of potatoes in small local markets (haats) located on average 5 kilometres outside the village.
} 
reports are about much larger wholesale markets than the ones where traders resell potatoes from these villages. Although public telephone booths, landline phones at home and mobile phones were all available to varying extents, farmers told us in informal interviews that they had no contacts at mandis who would share price information with them.

Our fortnightly survey data also indicated substantial information asymmetry between farmers and traders. When we asked farmers what the price in the neighboring market had been recently, their price reports did not match the mandi prices (received by the village traders) in the relevant week, but instead were much closer to the prices received by farmers who sold at a haat in that week. ${ }^{8}$ The average price reported (Rupees 2.57 per $\mathrm{kg}$ ) was close to the gross price at which farmers sold in haats (Rupees 2.55 per $\mathrm{kg}$ ), and substantially different from the average gross price at which traders sold at the wholesale market (Rupees 4.82 per $\mathrm{kg}$ ). ${ }^{9}$ In other words, they interpreted the "market price" as the price they would receive if they took their potatoes to the haat, not the price at which middlemen resold their produce at the mandi.

We received the mandi price reports from market "insiders", who were either employees of the distant buyers, or small entrepreneurs (e.g. tea shop owners) located at the markets, and observed trades at the wholesale level. They were persuaded by our investigators to give us this information on a daily basis, in return for a fee.

\footnotetext{
${ }^{8}$ They also told us how many days ago they had tracked this price. Combined with the date of the survey, this allows us to estimate the week that they reported their tracked price for, and match their report to the actual price in that week.

${ }^{9}$ The gross price at which a farmer sold at haats is computed by dividing the total revenue he received from selling at a market across all weeks in the year, by the quantity sold. Rupees 2.55 is the average of this number across all farmers who sold at haats.
} 


\subsection{Margins Earned by Traders}

Estimating the margins that middlemen earn is not straightforward because they often hold potatoes after buying them, and sell them later in the year when the price is high. However since they have the option of re-selling at the same time as they buy, the difference between their selling and buying prices at the same point of time provides a lower bound to their expected gross margin. Since we do not have data on the actual costs that traders incurred, we use unit cost data for transport, handling and storage from farmer surveys as estimates. To the extent that traders can avail of economies of scale and connections with store-owners and so incur lower unit costs than farmers these are an upper bound to the traders' costs; subtracting them from gross margins then yields a lower bound to trader net margins.

Lower bounds to trader net margins need to be calculated separately for harvest and post-harvest periods. ${ }^{10}$ Using average prices for the harvest and post-harvest season (using the distribution of quantities sold in the sample in different weeks as weights), lower bounds to trader gross margins were Rs. 2.59 per $\mathrm{kg}$ during the harvest period (the average selling price was Rs 4.81 and buying price was Rs 2.22 ), and Rs 2.72 during the post-harvest period (the average selling price was Rs 4.83 and buying price was Rs 2.11). Sample farmers who sold potatoes at haats incurred transport costs of Rs. 0.23 per $\mathrm{kg}$ in the harvest period (and zero in the

\footnotetext{
${ }^{10}$ This is because for potato transactions occurring in the harvest period, storage costs would not be incurred, while transport costs would be incurred: the trader would buy potatoes from the field, have them cleaned, sorted and transported to the mandi and then loaded directly onto trucks sent by buyers. In transactions occurring after June, the trader would buy potato bonds from farmers, pay storage charges to release the potatoes from the cold store, then have them dried, sorted, colored and loaded into the buyers' trucks. (Most cold storage facilities are located near mandis.) They would incur storage costs, but no transport costs because these would have been incurred by farmers who had earlier placed them in the store.
} 
post-harvest period because those sales occur at cold store which are located close to the mandi), handling costs of Rs. $0.35 / 0.45$ per $\mathrm{kg}$ in the harvest/post-harvest period, and storage costs Rs. 0.91 per $\mathrm{kg}$ for post-harvest sales. ${ }^{11}$

This generates the following lower bounds on mean net trader margins in 2008:

Middleman margin $=\left\{\begin{array}{l}\text { Rs.4.81-2.22-0.39-0.35 }=\text { Rs.1.85 per kg at harvest time } \\ \text { Rs. } 4.83-2.11-0.45-0.91=\text { Rs. } 1.36 \text { per kg after harvest time }\end{array}\right.$

Middlemen therefore earned at least 28 to 38 percent of the mandi price, and 64 to 83 percent of the farm-gate price, depending on which part of the year they bought and sold the crop in. ${ }^{12}$

\section{The Experiment and the Data}

Our experiment was conducted in 72 villages chosen through a stratified random sampling procedure in the potato growing areas (blocks) of Hugli and West Medinipur districts. To reduce information spillovers, we ensured that sample villages were at a minimum distance of 10 kilometres from each other. ${ }^{13}$ Sample villages in each block were randomly assigned to three groups, resulting in 24 villages in each

\footnotetext{
${ }^{11}$ Cold stores charge a flat rate regardless of how long the potatoes are stored. Also, since farmers transport potatoes to haats that are on average 5 kilometres away from the village, whereas traders transport them to mandis on average 8 kilometres away, we make a proportional adjustment and revise traders' unit cost of transport to Rs. 0.39 for harvest transactions.

${ }^{12}$ These numbers are similar to those found in previous work: In his 1998-99 study of 136 potato farmers in the Arambagh block of Hugli district, Basu (2008) found that middlemen margins net of transactions costs were 25 percent of retail price in the busy season, and 20 percent in the lean season. Farmgate prices were between 49 and 36 percent of the retail price.

${ }^{13}$ In informal interviews conducted in the area in 2006 before our sample was drawn, we found that in the regular course of events the typical farmer tended to travel no more than 10 kilometres out of the village. We therefore chose this distance to ensure that information would not spread from information villages to control villages.
} 
treatment group. ${ }^{14}$ In two groups we conducted two different information treatments, while the third served as the control where no information was provided. In the two treatment groups, we delivered daily information about the prices in one or two nearby mandis and the nearest city market. This was the average daily price at which traders re-sold (physical) potatoes to buyers located in markets further away, collected by our field team from market "insiders", as described in Section 2.2. In our analysis below we refer to this as the mandi price.

In the 24 private information villages, the price information was given individually to 4 households selected randomly from our survey households. Every morning for 11 months, the "tele-callers" based in our Kolkata information center relayed the mandi prices from the previous evening to each of these farmers via mobile phones that were given to them for the purpose of the project. To ensure that the phones were used only for information provision and did not improve the farmers' connectivity more generally, we asked the service provider to block outgoing calls from the phones, and changed the phone settings so farmers could not view their own phone number. We did not inform the farmers of their mobile phone numbers, and all phone bills were delivered to us. This prevented the farmer from receiving any incoming calls except from us. ${ }^{15}$

In the 24 public information villages, we delivered the mandi price information to a local shopkeeper or phone-booth owneer (called the "vendor") in the village. For a nominal fee, he wrote the price information on charts and posted them in

\footnotetext{
${ }^{14}$ Each village was then mapped to the mandi(s) that were closest to it, which is where potatoes grown in that village tended to be re-sold by traders. Since most villages in a block have the same one or two mandis under their purview, this effectively ensures that under a given mandi there are villages randomly assigned to different information treatments.

${ }^{15}$ Since we had access to the log of calls for each phone, we were able to check that our restrictions were effective.
} 
three public places in each village. ${ }^{16}$

The information interventions were piloted in the sample villages during JuneNovember 2007. The actual experiment began in January 2008 and continued daily until November 2008. All villages and households were in the same treatment or control group in 2008 as they were in 2007. All empirical estimates of the interventions on farmer quantities and revenues will be presented for the 2008 data.

The magnitude of our sample is so small relative to the catchment area of a mandi, that it is unlikely that our experiment changed the prevailing mandi prices. The total volume of potatoes sold by our sample farmers in 2008 was less than 1 percent of the total volume traded in the large mandis in this area. ${ }^{17}$

\subsection{Data}

Our datasets come from household surveys conducted with a stratified random sample of 24 potato-growing households in each of the 72 villages in our study. ${ }^{18}$ The analysis in this paper is restricted to the 1545 sample farmers who planted either one of the two main varieties (jyoti and chandramukhi) of potatoes in $2008 .{ }^{19}$

A production survey was conducted in February to collect data about the planting and cultivation of potatoes, including area planted, inputs used, output har-

\footnotetext{
${ }^{16}$ If farmers asked the tele-callers or vendors why they were being given this information, they were instructed to say this was part of a research study, but that they did not know why this was being done or how farmers could use this information.

${ }^{17}$ Data on trade volume in large mandis were taken from the Government of India's Agmark dataset that reports daily price information in the large mandis in all states of India, for major agricultural crops.

${ }^{18}$ In 2006 we conducted a census in all sample villages to record which households had planted potatoes that year. We then stratified all potato-growing households by landholding category and drew a random sample from each stratum.

${ }^{19}$ These two varieties accounted for 70 and 20 percent, respectively, of the potatoes grown in 2008.
} 
vested, and allocation of harvest across different uses. The questionnaire also included questions about household demographics, assets, land ownership and credit. Next, a trade survey was administered to all sample households each fortnight between February and November. This collected information on each individual potato sale that the farmer had made in the previous fortnight: whether the potatoes were sold from the field, from home stores or cold stores, the variety and (self-reported) quality of potatoes, the quantity sold, place where the exchange took place, costs incurred by the farmer to undertake the sale, and the payment received. ${ }^{20}$

Clearly at the weekly level, farmers solve a dynamic optimization problem to choose when and how much to sell. To analyze the weekly decisions of potato sales we would have to build a dynamic model taking into account the effect of the interventions on farmers' price expectations. Instead, we take advantage of the fact that all potatoes must be sold within a year of being harvested, and simplify the analysis by aggregating the data to the annual level.

\subsection{Descriptive Statistics}

Table C1 shows a number of village and households characteristics by treatment groups, from data collected before the pilot information interventions began in June 2007. Villages were on average 8.5 kilometres away from the mandis whose price information we provided. About half the villages had a public telephone booth.

As Panel B shows, the average landholding size of sample households was 1.1 acres. Since we drew the sample from potato farmers in 2007 nearly all farmers in

\footnotetext{
${ }^{20}$ When payment was deferred, we followed up with the farmer in subsequent rounds to record the date and the amount of each installment received.
} 
the survey reported planting potatoes (Panel C). Among these farmers, nearly $94 \%$ had planted the jyoti variety in 2007. The total area planted with potatoes in 2007 was 0.9 acres, and on average farmers harvested 7056 kilograms. They sold about 80 percent of these through the year, at an average price of Rupees 2.9. Nearly all of this quantity was sold to traders in the village, and less than 1 percent was sold to traders located outside the village.

For most village characteristics, the pre-intervention differences across treatment groups were small and insignificant. A notable exception is that control villages had a much higher probability of having a public telephone box. However this is the result of a random draw. Mandi fixed effects in our regressions will control for such differences at the village level. ${ }^{21}$

To evaluate if the household-level variables in Panels B, C, D and E are jointly different across the treatment and control groups, we run a test that all householdlevel variables are significantly different from each other. The p-values are provided at the bottom of Table C1. All three tests are rejected at conventional levels of significance.

\subsubsection{Effect of Information Treatments on Farmers' Price Information}

In the fortnightly trade surveys, we asked farmers about the frequency at which they tracked prices in wholesale and retail potato markets and whom they gathered this information from. ${ }^{22}$

\footnotetext{
${ }^{21}$ Sample villages are mapped to the wholesale market whose catchment area they lie in, and in the information interventions, farmers/village vendors received the price information from that market. We define a mandi as a market-potato variety combination. For example, both jyoti and chandramukhi potatoes are traded at Bhandarhati market, which generates two mandis for the purposes of our analysis: Bhandarhati-jyoti and Bhandarhati-chandramukhi.

${ }^{22}$ To guard against "demand effects" from asking survey questions that made our intervention salient, these questions were asked only to a randomly selected one-half of the sample. As a result we have these data at the fortnightly level for 853 farmers. As we show in Table C10 in the
} 
To analyse whether the interventions changed farmers' price tracking behavior, we use the specification

$y_{i v t}=\beta_{0}+\beta_{1}$ Private Information $_{v}+\beta_{2}$ Phone Recipient $_{i v}+\beta_{3}$ Public Information $_{v}+\beta_{4} X_{i v t}+\epsilon_{i v t}$

where $y_{i v t}$ measures the dependent variable for farmer $i$ in village $v$ in fortnight $t$. The dependent variables are whether the farmer reports tracking wholesale prices (Table 4, Panel A, Column 1), the number of days since he last tracked prices (Column 2), and who his source of information is (Column 3). Accordingly, we use a logit specification in Column 1, and a Poisson regression in Column 2. For Column 3 , we re-code the farmer's response to identify whether the source of information included the experimental treatment, or not, and then run a logit regression. ${ }^{23}$ Control variables include a dummy for the potato variety (jyoti or chandramukhi), district, and the survey month. For convenience we report exponentiated coefficients in all three columns.

The results in columns 1 and 2 indicate that the intervention did work as planned: farmers who received the interventions were more likely to track market prices and, conditional on tracking prices, to have done so more recently. Column 3 shows that farmers in the information intervention groups were more likely to have received price information from a source in the "other" category. This category includes the tele-callers who provided information to farmers, and the public notice boards (see footnote 23). The effect was larger in the public information treatment

Appendix, the results reported in Tables 6, C6 and 7 continue to hold even if we analyze only the subset of households that were not asked questions about their price-tracking behaviour.

${ }^{23}$ To avoid "demand effects", we did not offer a category indicating our intervention. The list of categories provided was, in order: friends, relatives, neighbours, caste members, traders, local government officials, NGO employees, cooperative members and other. Since the farmers chose the category "other" over all the previous categories, we interpret their report as indicating the price information intervention. 
than in the private information treatment, and within the private information treatment, was larger for phone recipients.

Panel B in Table 4 shows that the intervention improved the precision with which farmers tracked prices. We match the prices that farmers reported with the actual prices in the markets that they reported tracking. As stated in Section 2.2, the average price that farmers reported was similar to the price they would have received if they had sold to a trader in a local market (haat), rather than the trader's resale price. Nevertheless, the information did reduce the error in this price. The average sum of squares of the normalized error in reported price is significantly lower for intervention households than for control households. It is not significantly different between phone non-recipients and phone recipients, or between the private and public information treatments. ${ }^{24}$

\section{Alternative Trading Mechanisms}

We now describe alternative models of the farmer-trader trading mechanism, and discuss their predictions about the effects of the information interventions.

\subsection{Contracts with Full Commitment}

An ex ante contract would specify the quantity that the farmer sells and the price (or equivalently the total revenue) the trader pays, at each realization of the mandi price $\nu$ (as reported by the trader to the farmer). This would allow traders to insure farmers against price risk. The middleman margins could then conceivably

\footnotetext{
${ }^{24}$ The reader may wonder why, if the interventions did not cause farmers to report the actual mandi prices, they still reduced the error in their reports. It is likely that the information provided helped farmers infer the price they could get if they sold in the haat, and that this is how they interpreted questions about the "market price".
} 
represent risk premia on such insurance. The context here is essentially the same as for implicit wage-employment contracts where workers do not know the price at which employers sell the firm's product (Hart 1983). In such a setting if traders are risk-neutral and farmers are risk-averse, traders insure farmers perfectly by paying them a constant price regardless of the mandi price. Then traders have no incentive to understate the mandi price; hence their private information does not create any distortions.

Asymmetric information generates distortions only if traders are also riskaverse, so that in the equilibrium contract, farmers also bear part of the risk associated with mandi price fluctuations. When this is the case, traders have an incentive to understate the mandi price, so as to offer the farmer a low price. To keep them honest, traded quantities are (sub-optimally) low when the mandi price is low. Information interventions that reduce the asymmetry of information would reduce this screening distortion, and cause the quantity traded at low mandi prices to increase. Thus mutual risk-sharing contracts with asymmetric information would predict a positive average treatment effect on quantity transacted, and the treatment effect would especially be positive in low-market-price states.

\subsection{Contracts with Limited Commitment}

In ex ante contracts with risk-sharing, traders commit to providing a minimum price to farmers, and incur losses when the mandi price falls below this minimum. In exchange, farmers must sell to the trader at below the mandi price when the mandi price is high. If farmers know actual mandi prices and are able to sell directly at the market (which we have seen they are not, in this context), they would be tempted to renege on the ex ante contract when the mandi price is high. Providing 
mandi price information to farmers can aggravate their temptation to renege, and cause the insurance arrangement to unravel. In turn this would cause the farmgate price to co-move more with the mandi price, and farmers would sell directly outside the village more often.

Since our potato farmers were unable to sell directly to buyers at the wholesale markets they have no choice but to sell to middlemen and there is no scope for ex post moral hazard. We do not consider lack of commitment by middlemen: since they are perfectly informed about the price in any case there is no reason for information provision to change their scope for opportunistic behavior.

\subsection{Simultaneous Oligopolistic Interaction}

Standard trade and IO models of price pass-through in vertical supply chains use monopolistic competition models in the spirit of Dixit and Stiglitz (1977). These involve a simultaneous move game where middlemen (who may be differentiated on non-price dimensions) select their respective prices (see e.g., Atkin and Donaldson 2014, Gopinath and Itskhoki 2010, Weyl and Fabinger 2013 and Villas-Boas 2007). Perfect competition and perfect collusion are limiting special cases. In these models, traders offer prices simultaneously, and farmers respond either by selecting one of these offers and a corresponding quantity to sell, or by remaining in autarky. Providing information to farmers does not change anyone's payoff function: farmer payoffs depend only on the price offers of the traders (since they cannot sell directly in the market themselves), and traders already know their resale price. ${ }^{25}$

\footnotetext{
${ }^{25}$ As we shall see in the next section, this relies critically on the simultaneous move assumption. When traders move sequentially the equilibrium can be affected.
} 


\subsection{Sequential Oligopolistic Bargaining}

As discussed above, farmers and traders described to us a process of ex post bargaining, where on each day, village traders observe the mandi price and then make a price offer to farmers. Farmers respond to the offer by choosing whether and how much to sell to the trader. On any given day, the farmer has a stock of potatoes. If he refuses the trader's price offer, he can either sell nothing that day, or incur the cost of transporting some potatoes to the haat, where he encounters other traders. These traders make a price offer to buy his potatoes and resell them in the mandi. If the farmer refuses this offer as well, he must either transport the potatoes back to the village at a cost, or else discard them. In our model, the trader in the haat is aware of this "hold-up" situation and so takes advantage of it by offering a low price. As a result the option of selling to a trader in the haat is not very attractive. Further, if village traders collude with one another, they can force the farmer down to a low price. ${ }^{26}$

The other key simplifying assumption is that all village traders collude, and all traders in the haat collude, but the set of village traders and the set of haat traders compete with one another. In other words, there is a single representative village trader (denoted VT), who competes with a single representative market (haat) trader (denoted MT). Importantly, since VT is located in the farmer's village, he has a spatial first-mover advantage. Suppose the risk-neutral farmer F has a stock of $\bar{q}$ potatoes. First, he makes a price offer $p$ to the farmer F. If $\mathrm{F}$ refuses this offer, he can incur a per unit cost of $t$ and transport the quantity $q_{2}$ to the haat. There he approaches market trader MT, who offers him price $m$. If the farmer refuses this

\footnotetext{
${ }^{26}$ As discussed in Section 3.1, we abstract from the dynamics of sales decisions and instead consider a single date when the farmer must either sell or consume all potatoes.
} 
offer as well, he transports the potatoes back to the village to consume them. ${ }^{27}$ We assume that it is common knowledge that both MT and VT can re-sell the potatoes at the mandi at price $\nu$ (net of transport costs), and that they both know the realization of $\nu$, but that the farmer's prior information about the realization of $\nu$ is imperfect. Hence it is possible for $\mathrm{F}$ to make inferences about the realization of $\nu$ after he views the price offers by traders. ${ }^{28}$

Sequential competition between VT and MT makes it possible for an information intervention to affect trading outcomes. ${ }^{29}$ To see this, consider the possible equilibria in this set-up. One possibility is a perfectly separating equilibrium such that VT's price offer to F varies monotonically with the realization of $\nu$ (see Figure B1a). Other possibilities include either complete pooling (the price offer to $\mathrm{F}$ is constant regardless of the level of $\nu$ ) or partial pooling (the price offer is constant over particular ranges of $\nu$ levels, see Figure B1b). As these ranges get narrower, we say that there is a lower degree of pooling and the equilibrium begins to approach a separating equilibrium.

In either case, we can use backward induction to solve for MT's price offer to F. MT has an ex post monopsony, and also can "hold up" F because of the additional cost that $\mathrm{F}$ must incur to transport potatoes back to the village if he were to refuse MT's offer. Call the ex post optimal price offer by MT $m(\nu)$, where $m(\cdot)$ is strictly increasing in $\nu$ under standard distributional assumptions. Since F's outside option at this last stage is only autarky, this price offer is not directly dependent on F's information about $\nu$.

\footnotetext{
${ }^{27}$ We simplify by assuming that the value of self-consumption is large enough relative to the transport cost that it will always be in the farmer's interest to bring all the potatoes back.

${ }^{28}$ The Appendix provides a detailed analysis of the bargaining game with sequential competition between VT and MT.

${ }^{29}$ Although we assume here that the farmer is risk-neutral over the revenue he earns from selling potatoes, the results about the separating equilibrium below continue to hold if he is risk-averse.
} 
At the first stage of bargaining between F and VT, F's outside option is MT's offer $m(\nu)$. The $m(\nu)$ function is commonly known to all three parties. VT's optimal price offer is designed to make $\mathrm{F}$ indifferent between accepting it, and rejecting it and approaching MT instead. However, whether F chooses to accept or reject this offer depends on what this price offer tells him about $\nu$. This in turn depends on whether the equilibrium is separating or pooling.

In a separating equilibrium, VT's offer $p(\nu)$ is the monopsony price for VT, given the ex post outside option for $\mathrm{F}$ represented by the price $m(\nu)$, and the transport costs of taking the potatoes to the market. The price $p(\nu)$ makes $\mathrm{F}$ indifferent between accepting and rejecting VT's offer. It therefore contains information for $\mathrm{F}$ : for a given $\nu$, a high $p(\nu)$ suggests that $\nu$ is high, which suggests that $m(\nu)$ will be high as well. It therefore increases the probability that F rejects VT's offer and instead tries to sell in the market. To avoid this possibility, VT has an incentive to offer a lower $p(\nu)$, in order to make $\mathrm{F}$ indifferent between selling to him and not. As a result, $p(\nu)$ is strictly increasing in $\nu$ (thereby revealing $\nu$ perfectly), but is lower than VT's ex post monopsony price would have been if there had been no information asymmetry.

The separating equilibrium is not directly relevant in our context, because it would have effectively informed farmers about the wholesale price, so there would be no asymmetry of information. Instead we focus on the class of pooling equilibria where in the baseline, farmers had less information about the mandi price than the traders did. In a pooling equilibrium, village traders make price offers that do not vary with $\nu$ locally, and so conceal information about small variations in $\nu$. However, the price offer can shift up by a discrete amount at particular thresholds of $\nu$ (call these thresholds $\nu_{i}$ ), thereby revealing that $\nu$ lies in a specific range. The 
values of the thresholds $\nu_{i}$ and corresponding offers $r_{i}$ are such that the farmer is indifferent between accepting and rejecting VT's offer (on the equilibrium path), conditional on the information communicated by the offer. Therefore these values depend on the farmer's prior beliefs. Roughly speaking, the width of the pooling intervals $\left(\nu_{i-1}, \nu_{i}\right)$ depend on the farmer's information: the better informed he is, the narrower these intervals tend to be. ${ }^{30}$

There are many such pooling equilibria, and they vary in how much information is conveyed to the farmer by VT's price offer at Stage 1. For any given extent of asymmetric information and a given pooling equilibrium of this kind, there is also a set of pooling equilibria that provide more information to $\mathrm{F}$. In equilibria that convey more information, the intervals of the induced information partition of $\mathrm{F}$ are narrower, and the price offers are closer to those in the separating equilibrium.

The set of such pooling equilibria depends both on how much asymmetric information there is to start with, and on the degree of risk-aversion of the farmer. For the farmer to be indifferent between a pooled price offer and the price he expects to receive by rejecting it and going to the market instead, there must be an asymmetry of information. In other words, the farmer must be uncertain about what he will get at the haat, because otherwise he would be able to compare the two options directly and would not be indifferent. In some states of the world he will end up doing better ex post by rejecting the offer; in others he will be worse

\footnotetext{
${ }^{30}$ The price offers that VT makes in the pooling equilibrium are a local average of the price offers in the separating equilibrium, since they are tied down by a similar indifference property between acceptance and rejection for the farmer. The average is rough, since the price offer made by VT conceals information about $\nu$ from the farmer, which in turn affects what the farmer expects from carrying the potatoes to the haat. The price offer affects the quantity of potatoes he transports to the haat; he may find that he has taken less than MT is willing to buy, or that he has taken more and has to cart the excess back to the village. The outside option payoff of $\mathrm{F}$ from rejecting VT's offer is therefore not the same as in the separating equilibrium, and is itself influenced by the offer.
} 
off. The set of pooling equilibria converges to the separating equilibrium as the extent of asymmetric information vanishes in the limit.

Reducing the extent of asymmetric information through an external intervention would eliminate equilibria with a high degree of pooling. ${ }^{31}$ To see the implications of this, consider the case where we move to an equilibrium close to the separating equilibrium where increases in $\nu$ cause increases in $p(\nu)$, whereas earlier they did not result in any change in VT's offer. This implies that $p(\nu)$ will fall when $\nu$ is at the low end of the range of pooling, and rise when it is at the high end. On average, due to the indifference property of the original pooling equilibrium, the price offer will remain unaffected. This implies that the farmer's quantity response and revenues earned will remain unaffected on average, but will become more responsive to movements in $\nu$.

The ex post bargaining model therefore generates a number of implications which can be tested empirically.

(i) If initially the market is in a pooling equilibrium that is vulnerable to an information treatment in the sense described above, the information intervention causes farmers in the village to become better informed about the mandi and local market (haat) price.

(ii) If initially the market is in a vulnerable pooling equilibrium, the intervention has zero average effects on traded quantities and farmgate prices. It increases the pass-through of mandi prices to farmgate prices, and correspondingly

\footnotetext{
${ }^{31}$ We assume that the information interventions do not themselves change the market structure of village traders and thereby the nature of their contracts with farmers. This is supported by data on trader market concentration from trader surveys conducted in 2011-12 for a different study, where also price information was provided in a random set of villages. Even after nearly 3 years of price information provision, we cannot reject the hypothesis that the Herfindahl index of trader concentration was no different in information versus non-information villages.
} 
increases the volatility of traded quantities and farmer revenues. ${ }^{32}$

(iii) The farmgate price $(p)$ is always lower than the price $(m)$ the farmer receives at the market. In a separating equilibrium, this is because the farmer is indifferent between selling to VT and selling to MT, where he sells to the MT a sub-optimally low quantity, due to the hold-up problem. In a pooling equilibrium, this is aggravated by the risk-averse farmer's uncertainty about the MT's price offer.

(iv) As $\nu$ increases, and VT makes a higher price offer, the farmer is more likely to reject the offer and sell to MT in the haat. This is because a higher price offer by VT signals to $\mathrm{F}$ that $\nu$ is high, and therefore $m$ will be high as well.

(v) If transport costs rise and everything else is unchanged, $m(\nu)$ shifts down, and the gap between $p(\nu)$ and $m(\nu)$ increases. F accepts VT's offer less often and sells to MT more often.

\section{Empirical Analysis}

We now turn to empirical tests of the theoretical predictions above.

\subsection{The Unpredictability of Mandi Prices}

The key premise in this project is that farmers have less information about prices prevailing in the mandi than traders do. We have described anecdotal evidence that farmers cannot collect information from the mandis. Below we argue that farmers also could not have extracted much information from past farmgate prices or current local yields.

\footnotetext{
${ }^{32}$ If the initial equilibrium is separating or has a small degree of pooling, there is no effect on either pass-through or volatility.
} 
First, there is considerable variation in mandi prices from year to year. The average price per kilogram in the post-harvest period across all mandis in our sample was Rs 7.60 in 2007, Rs 4.83 in 2008, Rs 5.55 in 2011 and 10.99 in 2012. Second, there is considerable volatility in weekly mandi prices both over time and across mandis, and a substantial part of the variation remains unexplained even after controlling for location-specific characteristics, seasonality and annual shocks. ${ }^{33}$ To see this consider the analysis of variance of weekly mandi prices for weeks 13 and beyond in 2007, 2008, 2011 and 2012 presented in Table 2. As the Fstatistics show, the highest variability occurs across years, followed by period-year variations and spatial mandi-level variations. Prices also follow different patterns in different periods of time within the same year. ${ }^{34}$ Finally, different mandis follow different patterns from year to year.

It is also unlikely that farmers could infer the current prices at their local mandi from readily observable data such as the distance of the mandi from the city market, transport cost fluctuations or potato output shocks in their area. The first column in Table 3 presents the result of a regression on a pooled cross-section of annual mandi prices for 2007, 2008, 2011 and 2012, on various factors that could explain the annual variation: average wholesale price in the relevant destination city market (Kolkata for Hugli, Bhubaneswar for West Medinipur), distance between the mandi and the city, interactions between distance and city price (representing fluctuating transport costs) local potato yields (from output data for sample farmers located in

${ }^{33}$ Although in 2008 we collected mandi price data from January to November, for 2007, 2011 and 2012 we have these data only for the period May-November, and so this analysis is restricted to the post-harvest period. However in Section 5 we will analyze all sales that occurred in 2008, regardless of timing.

${ }^{34}$ Weeks 13 to 26 are considered to be the post-harvest early period when farmers could be selling home-stored potatoes, and weeks $26-52$ are the post-harvest late period, when any potatoes being sold are coming out of cold storage. 
each mandi area), and measures of local infrastructure measures. ${ }^{35}$ Year dummies control for annual shocks to the price. The regression coefficient on the city price is 0.84 and significant at $1 \%$, but the other mandi-specific time-varying factors do not predict the mandi price. (We will include mandi fixed effects in our impact regressions to control for fixed factors.) Column 2 presents a similar regression using weekly mandi prices, controlling for mandi, week and year fixed effects. Once again, city prices explain mandi prices significantly. Local yields do not. This is also true in Column 3, where the sample excludes data points in 2008, the year of our study.

Finally, it would be very difficult for farmers to back out the prevailing mandi price by observing the price that the trader offered them. Column 4 of Table 3 presents a regression of weekly farmer prices in 2008 on the city price and local yields, controlling for mandi dummies and week dummies. The pass-through coefficient is 0.02 and is statistically insignificant from zero. Thus, farmer prices do not co-move with city prices, whereas mandi prices do.

Given this lack of information, we also find evidence in favor of the first prediction of the model: as shown in Table 4 and discussed in Section 3.2.1, farmers in the information treatment groups provided more precise reports of the market prices than farmers in the control group did.

\subsection{Average Treatment Effects}

We now examine the second prediction by estimating the effect of the interventions on the farmers' sales and revenues. For each farmer we know each variety produced and sold, and the (self-reported) quality of potatoes in each transation. Our data are thus at the level of farmer-variety-quality, and the regressions include variety

\footnotetext{
${ }^{35}$ These annual averages are computed only for weeks 13 and beyond. See footnote 33.
} 
and quality dummies. This helps address the concern that farmers may react to low farmgate prices by selling potatoes of lower quality, or a different variety, or that traders react to low mandi prices by purchasing lower quality potatoes.

Table 5 shows the average effects of the information intervention on annual quantity sold and total revenue received by farmers (net of transactions costs paid by the farmer). ${ }^{36}$ The unit of observation is a farmer-variety-quality combination. Besides variety and quality dummies, we include a district dummy for West Medinipur, and control for the landholdings of the farmer. All standard errors are clustered at the village level to account for correlated error terms across different farmers in the same village. The regression specification is as follows:

$y_{i k q v}=\beta_{0}+\beta_{1}$ Private information $_{v}+\beta_{2}$ Phone recipient $_{i v}+\beta_{3}$ Public information $_{v}+\beta_{4} X_{i k q v}+\epsilon_{i k q v}$

where $y_{i k q v}$ is the dependent variable: gross revenue, net revenue received from the sale of, or annual quantity of variety $k$ and quality $q$ sold by farmer $i$ in village $v$. Private information and Public information are dummy variables indicating the treatment group that the farmer's village is assigned to. In the villages that received the private information treatment, the four randomly chosen households who received information directly via mobile phone also received a value of 1 for the Phone recipient dummy. Hence the coefficient on Private information should be interpreted as the effect on farmers whose village received the private information treatment, but who did not personally receive phonecalls. Their outcomes

\footnotetext{
${ }^{36}$ These are our main dependent variables, since there is no problem with aggregating quantities or revenues across different transactions. In contrast, the calculation of an average farmgate price is subject to an index number problem. Since the theoretical predictions can be equivalently rephrased in terms of effects of the information interventions on quantities and revenues rather than quantities and prices, we choose to use revenues. However Columns 1 and 2 of Table C4 in the Appendix show that the effects on average prices are qualitatively similar.
} 
would presumably be affected through the spread of information within the village. Standard errors are clustered at the village level.

The identifying assumption here is that access to information is exogenous to farmer or mandi characteristics that might drive sales and revenues. This assumption is delivered by the randomization of the information treatment. Recall also from Table $\mathrm{C} 1$ that there are no significant differences in observable characteristics of the villages in the three treatment groups.

Column (1) does not include mandi fixed effects. The sign of the coefficient is positive for all intervention dummies, but they are not significantly different from zero. In column (2) we include mandi fixed effects. This reverses the sign of the private information and the public information coefficients, and they all remain insignificant, consistent with the theoretical predictions of the bargaining model. ${ }^{37}$ Columns (3)-(6) show that there is also no significant average impact of the intervention on gross or net revenue. Figure 2 provides a visual illustration of average weekly farmgate prices throughout the entire year corresponding to the two information treatments and the control areas, plotted on the same graph as the corresponding mandi prices. There is no discernible difference between the different farmgate price series.

\subsection{Heterogeneous Treatment Effects}

The second prediction of the ex post bargaining model in Section 4.4 also says that the intervention would have increased the volatility of the quantity farmers sold and the revenues they received. In other words, informing farmers about the mandi

\footnotetext{
${ }^{37}$ The fact that the estimated effects with mandi fixed effects are negative, makes it unlikely that the true effects are positive but simply not detected due to a lack of statistical power.
} 
price would have increased the quantity they sold if the mandi price was high, and lowered it if the mandi price was low. To examine this we use the regression specification:

$$
\begin{aligned}
y_{i k q v}= & \beta_{0}+\beta_{1} \nu_{i k m}+\beta_{2} \text { Private information }_{v}+\beta_{3} \text { Phone recipient }_{i v}+\beta_{4} \text { Public information }_{v} \\
& +\beta_{5}\left(\text { Private information }_{v} \times \nu_{i k m}\right)+\beta_{6}\left(\text { Phone recipient }_{i v} \times \nu_{i k m}\right) \\
& +\beta_{7}\left(\text { Public information }_{v} \times \nu_{i k m}\right)+\beta_{8} X_{i k q v}+\epsilon_{i k q v}
\end{aligned}
$$

where $\nu_{i k m}$ is the realized average price (or price shock) in the mandi $m$ that this farmer's village is in the catchment area of. Standard errors are clustered at the village level.

For these heterogeneous effects to be identified, it must be the case that the mandi price is uncorrelated with the error term in the regression. ${ }^{38}$ In particular, it is important that variation in mandi prices was not correlated with variation in unobserved characteristics that might also affect the pass-through of prices. As Table C3 shows, within district, mandis with above and below the median price were not significantly different in characteristics such as distance from retail market, access to metalled roads, agricultural wage rates, or presence of industry/manufacturing. There is some evidence (only in Hugli district) that the average yield was slightly higher in villages under the above-median mandi price, and that residents were less likely to have landline phones. However, these differences will be controlled for in our regressions by the mandi fixed effects. ${ }^{39}$ Below we also discuss a robustness check that will circumvent this concern.

\footnotetext{
${ }^{38}$ Recall that the block-stratified assignment of villages to treatment category ensures that under a given mandi there are villages randomly assigned to different information treatments. Also, the randomization took place before 2008 mandi prices were realised, and it follows from Section 5.1 that previous years' prices could not have predicted 2008 prices.

${ }^{39}$ Results are qualitatively similar when mandi fixed effects are not included.
} 
The results in Tables 6 and 7 correspond to quantity sold and farmer revenue (net of transactions costs), respectively. The different columns in this table use different specifications of the mandi price and different samples. Column 1 uses the mandi price for each farmer-variety combination in the sample, averaged over those weeks in which the farmer sold the variety. Thus it represents the average resale price the trader could have received for potatoes he purchased from this farmer, and so is the relevant variable to use in this regression.

Column 1 shows a positive coefficient on the mandi price average although it is not significant. The intercept effect on both the private and public information treatments are negative, and the interaction of the treatment with the average mandi price is positive. In other words, the information interventions caused farmers facing a low mandi price to sell a smaller quantity than they would have sold otherwise. However, at higher mandi prices, this negative effect was attenuated. ${ }^{40}$

The weights used in the farmer-specific mandi price average in Column 1 are endogenous to a farmer's decision to sell: if a farmer chooses to sell only when the actual mandi price is high, then this average is an overestimate of the true average mandi price the farmer was facing. This concern is addressed in Column 2 by instead using an average where the mandi prices in the different weeks of the year are weighted by the volume of potatoes sold in that week by sample farmers in control villages in that district. This average is exogenous to the farmer's decision to sell, but may be less relevant to the farmgate price. We continue to see a large

\footnotetext{
${ }^{40}$ The results indicate that for a (phone non-recipient) farmer facing the 10th percentile of mandi price, the private information intervention caused sold quantity to go down by a statistically significant $1090 \mathrm{~kg}$ (or 28 percent of the control mean), and the public information intervention caused it to go down by $1189 \mathrm{~kg}$ (or 31 percent). For a farmer facing the 90th percentile of mandi price, the private and public information caused farmers to sell an additional $1158 \mathrm{~kg}$ (or 30 percent) and $723 \mathrm{~kg}$ (or 19 percent) respectively, although these two positive effects are not statistically significant.
} 
and statistically significant negative intercept effect and positive slope effect of the private information interventions. The signs are similar for the public information treatment, although the slope coefficient is not precisely estimated.

As a robustness check, column 3 presents estimates that use a different price regressor. Note that in the bargaining model, information intervention has an effect because it informs the farmer that the mandi price is either higher or lower than the expected price. To test this idea directly, instead of using the actual mandi price as the regressor we use the deviation of the 2008 mandi price from the predicted price, using weekly mandi prices from 2007, 2011 and 2012 to generate the prediction. Under standard rational expectation assumptions, this mandi price "shock" ought to be orthogonal to farmers' ex ante price information and other relevant characteristics. ${ }^{41}$ Note the intercept effect of the interventions now measure the effect of the treatment for farmers selling in states where the expected mandi price equalled the actual (rather than at a hypothetical price of zero, as in the previous specifications). According to the model, in this case the intervention can have no effect on the equilibrium. The interpretation of the slope coefficient remains the same: it estimates the effect of the intervention when the actual price is above the expected price.

As expected, we see in column 3 that the intercept terms are non-significant. The effects of the information treatments on the slope coefficient are positive, and the one on the private intervention is statistically significant. ${ }^{42}$

\footnotetext{
${ }^{41}$ Since the explanatory variable is itself derived from estimates from other regressions, we report cluster-bootstrap standard errors, where the mandis are defined as the clusters.

${ }^{42}$ This implies that a farmer facing a negative price deviation (at the 10th percentile) who received the private (public) information intervention sold 1155 (441, not significant) $\mathrm{kg}$ less than he would have sold otherwise. A farmer facing a positive price deviation (at the 90th percentile) and the private (public) information intervention sold 2263 (158, not significant) $\mathrm{kg}$ more than otherwise.
} 
Table 7 provides corresponding estimates of treatment effects on net farmer revenue. ${ }^{43}$ The intercept and slope effects of the interventions have the same signs as those in the quantity regressions. In other words, the treatments caused farmer revenues to fall (resp. rise) for farmers facing low (resp. high) mandi prices. ${ }^{44}$

Recall that the ex ante contracting model in Section 4.1 predicted that the information intervention would remove the distortion at the low mandi price, and cause the quantity traded to increase. Instead, in Table 6 we saw exactly the opposite: the information interventions caused traded quantities to fall significantly when the mandi price was low. An additional check of the hypothesis of relational contracts is provided in Column 4 in Tables 6, 7 and C6. We restrict the sample to farmers who had been selling to the same trader repeatedly over the past three years prior to 2008. If relational contracts are at all prevalent, this is the sub-sample where they are most likely to occur, and we expect to see that the information interventions cause the quantity and farmer revenue to increase if the farmer faces a low mandi price. Instead, the pattern of results in Column 4 is consistent with the ex post bargaining model, although less precise than in the other columns, given the substantially smaller sample size.

\footnotetext{
${ }^{43}$ Results are similar for farmer revenue gross of transactions costs (Table C6), per-unit price (Table C5) and the logarithms of quantity sold (Table C7), gross farmer revenue (Table C8) and net farmer revenue (Table C9).

${ }^{44}$ Column 1 indicates that private information decreased the net revenue of (phone nonrecipient) farmers facing the 10th percentile of mandi prices by a Rupees 2596 (not significant), and the public information decreased it by a statistically significant Rupees 2863 (36 percent of the control mean). The private information increased the net revenue at the 90th percentile of mandi prices by a statistically significant $3332 \mathrm{~kg}$ (42 percent of the control mean). Column 3 indicates that the private information caused the farmer to earn Rs 2540 less in extreme negativedeviation states and earn Rs 5581 more in extreme positive-deviation states. The effects of the public information are not statistically significant.
} 


\subsection{Additional Predictions of the Bargaining Model}

The third prediction of the ex post bargaining model is that, irrespective of the initial equilibrium, at any realization of mandi price $\nu$, the price paid by the village trader is lower than the price the farmer receives at the haat. This is verified in Column 1 of Table 8: controlling for the prevailing mandi price, district and land ownership, farmers who sold in the haat received a statistically significant 36 paise (or 16 percent) more per $\mathrm{kg}$ than those who sold within the village.

A surprising prediction of the model was that when the village trader offers the farmer a higher price at higher levels of $\nu$, the farmer infers that the mandi price is high and so a high price can be obtained at the haat. He is therefore more likely to reject his offer. This is verified in Column 2 of Table 8 , which shows that the farmer was more likely to sell in the haat when the mandi price is higher, after controlling for land ownership. In column 3 we also control for the Medinipur district dummy and we continue to find the positive relationship between mandi price and the likelihood that the farmer sold at the haat.

Finally, the model predicted that with higher transport costs, the price that MT offers is lower, and the gap between the price offers of VT and MT is larger, making it more worthwhile for the farmer to sell at the haat. In column 4 of Table 8 we find that holding mandi price constant, farmers located at a greater distance from the mandi were more likely to sell at the haat.

\section{Conclusion}

We have reported results of a field experiment providing market price information to potato farmers in the state of West Bengal in eastern India. Unlike other set- 
tings where producers have direct access to markets, large transactions costs and regulations prevent farmers in our context from selling to wholesale buyers directly, so that they must rely on local trade intermediaries (Cohen 2013). The effects of information provision in our context depend on the trading mechanism between farmer and trader.

Our findings are consistent with descriptions of the ex post bargaining mechanism reported to us in interviews by farmers and traders, involving sequential competition between a representative village trader and a representative trader located in the local market. At the same time the analysis provides evidence against explicit or implicit ex ante contracts involving trade pre-commitments or risk sharing. The results are also not consistent with models of monopsony, perfect competition or monopsonistic/oligopsonistic competition where middlemen make simultaneous price offers. Contrary to the predictions of all these models, information treatments had heterogenous effects depending on market price realizations: for farmers selling to traders who resold at low (high) prices, the treatments caused both quantities sold and farmer revenues to fall (rise).

The results suggest that the fundamental reason that farmers cannot benefit from interventions that reduce informational asymmetries is that they are unable to bypass the traders and sell directly in the wholesale market, or to other retail buyers. In turn this suggests that measures that improve farmers' price information are unlikely to be effective at reducing the large gaps between wholesale and farmgate prices; instead policy attention needs to be focused on enhancing farmers' market access. 


\section{References}

Aker, Jenny. 2010. "Information from Markets Near and Far: Mobile Phones and Agricultural Markets in Niger." American Economic Journal: Applied Economics 2 (July): 46-59.

Antras, Pol, and A. Costinot. 2010. "Intermediation and Economic Integrations." American Economic Review 100 (2): 424-428.

—. 2011. "Intermediated Trade." Quarterly Journal of Economics 126 (3): 1319-1374.

Atkin, David, and Dave Donaldson. 2014. "Who's Getting Globalized? The Size and Implications of Intranational Trade Costs." Yale University and MIT.

Bardhan, Pranab, and Dilip Mookherjee. 2011. "Subsidized Farm Input Programs and Agricultural Performance: A Farm-level Analysis of West Bengal's Green Revolution, 1982-1995." American Economic Journal: Applied Economics 3:186-214.

Bardhan, Pranab, Dilip Mookherjee, and Masatoshi Tsumagari. 2013. "Middleman Margins and Globalization." American Economic Journal: Microeconomics 5 (4): 81-119.

Basu, Jyotish Prakash. 2008. Marketing Efficiency and Marketing Channel: An Analytical Perspective of a Less Developed Region. Kolkata: Minerva Publications.

Blouin, Arthur, and Rocco Machiavello. 2013. "Tropical Lending: International Prices, Strategic Default and Credit Constraints among Coffee Washing Stations." University of Warwick.

Chau, N. H., H. Goto, and Ravi Kanbur. 2009. "Middlemen, Non-profits and Poverty." IZA Discussion Paper No. 4406.

Cohen, Amy J. 2013. "Supermarkets in India: Struggles over the Organization of Agricultural Markets and Food Supply Chains." University of Miami Law Review 68, no. 20.

Dixit, Avinash K., and Joseph E. Stiglitz. 1977. "Monopolistic Competition and Optimum Product Diversity." American Economic Review 67 (3): 297-308.

Fafchamps, Marcel, and Ruth Hill. 2008. "Price Transmission and Trader Entry in Domestic Commodity Markets." Economic Development and Cultural Change 56:724-766.

Fafchamps, Marcel, and Bart Minten. 2012. "Impact of SMS-Based Agricultural Information on Indian Farmers." The World Bank Economic Review, pp. 1-32.

Gopinath, Gita, and Oleg Itskhoki. 2010. "In Search of Real Rigidities." Harvard University and Princeton University. 
Goyal, Aparajita. 2010. "Information, Direct Access to Farmers, and Rural Market Performance in Central India." American Economic Journal: Applied Economics 2 (3): 22-45.

Hart, Oliver. 1983. "Optimal Labour Contracts under Asymmetric Information: An Introduction." Review of Economic Studies 50 (1): 3-35.

Jensen, Robert. 2007. "The Digital Provide: Information (Technology), Market Performance, and Welfare in the South Indian Fisheries Sector." The Quarterly Journal of Economics 122 (3): 879-924.

Ligon, Ethan, Jonathan P. Thomas, and Tim Worrall. 2002. "Informal Insurance Arrangements with Limited Commitment: Theory and Evidence from Village Economies." Review of Economic Studies 69:209-244.

Machiavello, Rocco. 2010. "Development Uncorked: Reputation Acquisition in the New Market for Chilean Wines in the UK." University of Warwick.

Machiavello, Rocco, and Ameet Morjaria. 2015. "The Value of Relationships: Evidence from a Supply Shock to Kenyan Rose Exports." American Economic Review. Forthcoming.

Maitra, Pushkar, Sandip Mitra, Dilip Mookherjee, Alberto Motta, and Sujata Visaria. 2015. "Financing Smallholder Agriculture: An Experiment with Agent-Intermediated Microloans in India." Boston University.

McMillan, Margaret, Dani Rodrik, and Karen Welch. 2002. "When Economic Reform Goes Wrong: Cashews in Mozambique." NBER Working Paper Number 9117.

Morisset, Jacques. 1998. "Unfair Trade? The Increasing Gap between World and Domestic Prices in Commodity Markets During the Past 25 Years." World Bank Research Observer $12(3): 503-526$.

Saenger, Christoph, Maximo Torero, and Matin Qaim. 2014. "Impact of Third-Party Enforcement of Contracts in Agricultural Markets: A Field Experiment in Vietnam." American Journal of Agricultural Economics.

Villas-Boas, Sofia B. 2007. "Vertical Relationships Between Manufacturers and Retailers: Inference with Limited Data." Review of Economic Studies 74 (2): 625-652.

Weyl, E. Glen, and Michal Fabinger. 2013. "Pass-through as an Economic Tool: Principles of Incidence under Imperfect Competition." Journal of Political Economy 121 (3): 528-585. 
Table 1: Self-reported contracting between farmer and trader

\begin{tabular}{|c|c|c|}
\hline & $\begin{array}{l}\text { oldest continuous seller } \\
\text { (1) }\end{array}$ & $\begin{array}{c}\text { newest supplier } \\
(2)\end{array}$ \\
\hline Had a prior agreement about purchasing potatoes from this farmer & 0.326 & 0.243 \\
\hline \multicolumn{3}{|l|}{ If prior agreement: } \\
\hline had explicitly agreed on the quantity to purchase & $\begin{array}{l}0.170 \\
(0.38)\end{array}$ & $\begin{array}{l}0.171 \\
(0.38)\end{array}$ \\
\hline had explicitly agreed on the price & $\begin{array}{l}0.043 \\
(0.20)\end{array}$ & $\begin{array}{l}0.143 \\
(0.36)\end{array}$ \\
\hline did not have explicit but implicit understanding about price & $\begin{array}{l}0.447 \\
(0.50)\end{array}$ & $\begin{array}{l}0.286 \\
(0.46)\end{array}$ \\
\hline had an understanding that farmer would not sell to anyone else & $\begin{array}{l}0.362 \\
(0.49)\end{array}$ & $\begin{array}{l}0.457 \\
(0.51)\end{array}$ \\
\hline had an understanding that trader would buy from this farmer & $\begin{array}{l}0.723 \\
(0.45)\end{array}$ & $\begin{array}{l}0.629 \\
(0.49)\end{array}$ \\
\hline farmer was free to sell to anyone & $\begin{array}{l}0.660 \\
(0.48)\end{array}$ & $\begin{array}{l}0.571 \\
(0.50)\end{array}$ \\
\hline trader was not obliged to buy from this farmer & $\begin{array}{l}0.149 \\
(0.36)\end{array}$ & $\begin{array}{l}0.057 \\
(0.24)\end{array}$ \\
\hline trader specified the harvest date & $\begin{array}{l}0.021 \\
(0.15)\end{array}$ & $\begin{array}{l}0.029 \\
(0.17)\end{array}$ \\
\hline
\end{tabular}

Standard deviations in parentheses. Traders could select multiple options, so percentages add to more than 100.

Table 2: Analysis of Variance of Weekly Mandi Prices

\begin{tabular}{lcc}
\hline Source & MSE & $\mathrm{F}$ \\
& $(1)$ & $(2)$ \\
\hline & 5117.97 & $8106.78^{* * *}$ \\
Year & 36.20 & $57.35^{* * *}$ \\
Period & 87.43 & $138.49^{* * *}$ \\
Year $\times$ Period & 81.57 & $129.2^{* * *}$ \\
Mandi & 26.55 & $42.06^{* * *}$ \\
Mandi $\times$ Year & \multicolumn{2}{c}{2845} \\
& \multicolumn{2}{c}{0.92} \\
Observations & \multicolumn{2}{c}{ R-squared }
\end{tabular}

An observation is a mandi-week for weeks 13 and beyond in years 2007, 2008, 2011 and 2012. ${ }^{* * *}: p<0.01,{ }^{* *}: p<0.05,{ }^{*}: p<0.1$. 
Table 3: Pass-through of City Prices to Mandi and Farmer Prices

\begin{tabular}{|c|c|c|c|c|}
\hline & \multirow{2}{*}{$\begin{array}{c}\text { Annual } \\
\text { mandi } \\
\text { price } \\
\text { all years } \\
\quad(1)\end{array}$} & \multicolumn{2}{|c|}{ Weekly mandi price } & \multirow{2}{*}{$\begin{array}{c}\text { Farmgate } \\
\text { price } \\
2008 \\
(4)\end{array}$} \\
\hline & & $\begin{array}{c}\text { all years } \\
(2)\end{array}$ & $\begin{array}{c}\text { excl. } 2008 \\
(3)\end{array}$ & \\
\hline City price & $\begin{array}{c}0.84^{* * *} \\
(0.108)\end{array}$ & $\begin{array}{c}0.81^{* * *} \\
(0.009)\end{array}$ & $\begin{array}{c}0.64^{* * *} \\
(0.018)\end{array}$ & $\begin{array}{c}0.02 \\
(0.068)\end{array}$ \\
\hline Distance to city ('00 km) & $\begin{array}{c}-0.34 \\
(0.304)\end{array}$ & & & \\
\hline City price $\times$ Distance to city & $\begin{array}{c}0.00 \\
(0.000)\end{array}$ & & & \\
\hline Local yield ('000 kg/acre) & $\begin{array}{l}-0.15 \\
(0.152)\end{array}$ & $\begin{array}{c}-0.03 \\
(0.020)\end{array}$ & $\begin{array}{c}0.02 \\
(0.027)\end{array}$ & $\begin{array}{c}0.05 \\
(0.582)\end{array}$ \\
\hline Percent households with landline phones & $\begin{array}{c}1.07 \\
(2.140)\end{array}$ & & & \\
\hline Percent villages with metalled roads & $\begin{array}{c}0.58 \\
(0.627)\end{array}$ & & & \\
\hline Percent villages with factories/mills & $\begin{array}{l}-0.80^{*} \\
(0.445)\end{array}$ & & & \\
\hline Year 2008 & $\begin{array}{c}0.88 \\
(0.599)\end{array}$ & $\begin{array}{c}0.40^{* * *} \\
(0.067)\end{array}$ & & \\
\hline Year 2011 & $\begin{array}{l}2.02^{* *} \\
(0.839)\end{array}$ & $\begin{array}{l}1.38^{* * *} \\
(0.083)\end{array}$ & $\begin{array}{c}0.66^{* * *} \\
(0.128)\end{array}$ & \\
\hline Year 2012 & $\begin{array}{c}2.40^{* * *} \\
(0.600)\end{array}$ & $\begin{array}{c}2.25^{* * *} \\
(0.073)\end{array}$ & $\begin{array}{c}2.50^{* * *} \\
(0.095)\end{array}$ & \\
\hline Constant & $\begin{array}{c}0.80 \\
(1.736)\end{array}$ & $\begin{array}{c}-0.59^{* * *} \\
(0.185)\end{array}$ & $\begin{array}{c}0.18 \\
(0.248)\end{array}$ & $\begin{array}{c}1.02 \\
(6.165)\end{array}$ \\
\hline Observations & 78 & 2,691 & 1,901 & 596 \\
\hline$R$-squared & 0.92 & 0.98 & 0.98 & 0.53 \\
\hline
\end{tabular}

In column 1 an observation is a mandi in a given year. In columns $2,3 \& 4$ it is a mandi in a given week. Week dummies are included in columns $2,3 \& 4$, and year and mandi dummies are included in columns 2 and 3. Robust standard errors are in parentheses. ${ }^{* * *}: p<0.01,^{* *}: p<$ $0.05,{ }^{*}: p<0.1$. 
Table 4: Effect of Interventions on Farmers' Tracking Behavior and Precision of Information

\begin{tabular}{lccc}
\hline & Panel A: Effect on Price Tracking Behavior & Track \\
& $\begin{array}{c}\text { Tholesale } \\
\text { price }\end{array}$ & $\begin{array}{c}\text { Days since } \\
\text { tracked }\end{array}$ & $\begin{array}{c}\text { Source of } \\
\text { informa- } \\
\text { tion } \\
\text { "other" } \\
\end{array}$ \\
& $(1)$ & $(2)$ & $(3)$ \\
\hline & & & \\
Private information & 0.805 & $0.692^{* * *}$ & $3.530^{* *}$ \\
& $(0.378)$ & $(0.069)$ & $(2.085)$ \\
Phone recipient & $1.818^{* *}$ & $0.796^{* * *}$ & $11.161^{* * *}$ \\
& $(0.549)$ & $(0.041)$ & $(5.987)$ \\
Public information & $8.596^{* * *}$ & $0.736^{* * *}$ & $52.173^{* * *}$ \\
& $(5.696)$ & $(0.081)$ & $(33.083)$ \\
Land & $1.578^{* * *}$ & 0.988 & 0.932 \\
Constant & $(0.209)$ & $(0.012)$ & $(0.071)$ \\
& $8.197^{* * *}$ & $4.945^{* * *}$ & $0.005^{* * *}$ \\
Observations & $(4.431)$ & $(0.501)$ & $(0.004)$ \\
Prob $>\chi^{2}$ & & & \\
Pseudo $R$-squared & 11,719 & 10,267 & 10,267 \\
\hline
\end{tabular}

Panel B: Effect on Error in Tracked Price Mean N

(1)

Control

Private information:

Phone non-recipient

Phone recipient

Public information

F-test of ratio of sum of squares (p-values)

Control/Private Info without phone

Control/Private Info with phone

Control/Public Info

Private Info/Public Info

Private Info without phone/Private Info with phone

\section{$0.221 \quad 3046$}

$0.190 \quad 2588$

$0.179 \quad 688$

$0.181 \quad 4714$

0.000

0.000

0.000

0.112

0.151

In Panel A, dependent variables are farmers' reports of whether they tracked prices in wholesale markets, the days since they last tracked prices, and their source of information, for a given potato variety, in the past fortnight. The farmer chose one source of information from a list presented in the following order: friend, relative, neighbour, caste member, trader, local government official, NGO employee, cooperative member, other. Dummy variables for potato variety, district and survey month are included in all columns. Standard errors in parentheses are clustered at the village level. In Panel B, the normalized "error" is the difference between the wholesale price he reports for a mandi in a given week and the average actual price in that mandi in that week. The reported means are the mean sums of squared normalized errors. ${ }^{* * *}: p<0.01,{ }^{* *}: p<0.05,{ }^{*}: p<0.1$. 


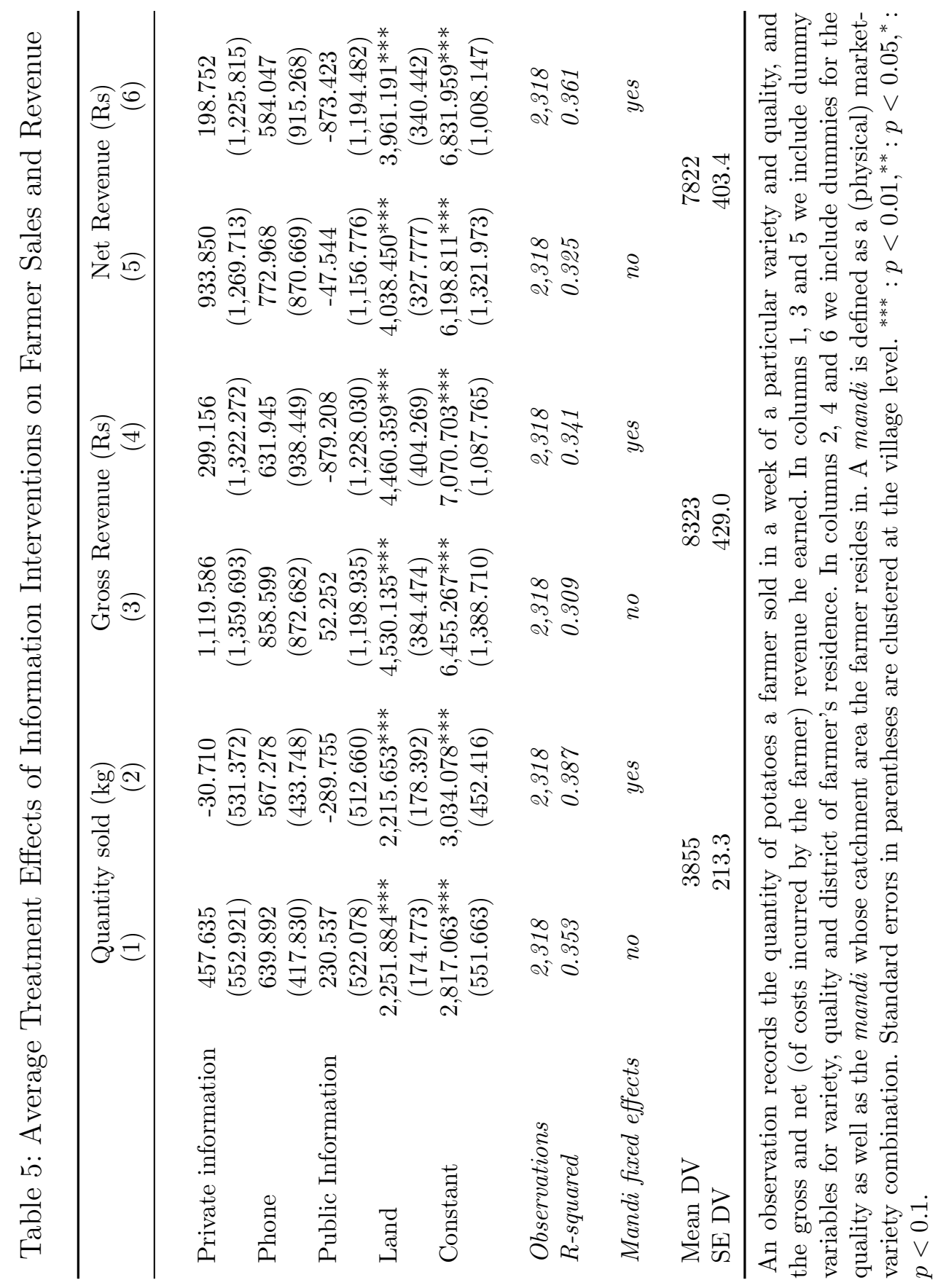


Table 6: Heterogeneous Impacts of Interventions on Quantity Sold

\begin{tabular}{|c|c|c|c|c|}
\hline & $\begin{array}{l}\text { Farmer- } \\
\text { specific } \\
\text { average } \\
(1)\end{array}$ & $\begin{array}{c}\text { Weighted } \\
\text { average } \\
(2)\end{array}$ & $\begin{array}{l}\text { Deviation } \\
\text { from } \\
\text { expected } \\
\text { mandi } \\
\text { price } \\
(3)\end{array}$ & $\begin{array}{l}\text { Long-term } \\
\text { relation- } \\
\text { ships } \\
\text { (4) }\end{array}$ \\
\hline Price regressor & $\begin{array}{c}76.6 \\
(242.8)\end{array}$ & & $\begin{array}{c}-252.2^{* * *} \\
(93.6)\end{array}$ & $\begin{array}{c}-819.3^{*} \\
(476.0)\end{array}$ \\
\hline Private information & $\begin{array}{c}-3,155.5^{* *} \\
(1,358.7)\end{array}$ & $\begin{array}{c}-3,910.5^{* *} \\
(1,774.3)\end{array}$ & $\begin{array}{c}562.5 \\
(676.3)\end{array}$ & $\begin{array}{c}-5,838.1^{*} \\
(3,144.5)\end{array}$ \\
\hline Private information $\times$ Price regressor & $\begin{array}{l}708.2^{* *} \\
(320.5)\end{array}$ & $\begin{array}{c}913.9^{* *} \\
(429.3)\end{array}$ & $\begin{array}{l}827.6^{* *} \\
(344.9)\end{array}$ & $\begin{array}{c}1,429.5^{*} \\
(815.1)\end{array}$ \\
\hline Phone & $\begin{array}{c}1,418.3 \\
(1,419.8)\end{array}$ & $\begin{array}{c}-66.8 \\
(1,578.9)\end{array}$ & $\begin{array}{c}621.8 \\
(664.6)\end{array}$ & $\begin{array}{c}3,344.0 \\
(4,040.3)\end{array}$ \\
\hline Phone $\times$ Price regressor & $\begin{array}{c}-200.9 \\
(332.1)\end{array}$ & $\begin{array}{c}145.0 \\
(411.2)\end{array}$ & $\begin{array}{c}-68.9 \\
(338.0)\end{array}$ & $\begin{array}{c}-724.8 \\
(1,058.4)\end{array}$ \\
\hline Public information & $\begin{array}{c}-2,946.1^{* *} \\
(1,263.4)\end{array}$ & $\begin{array}{c}-3,173.8^{*} \\
(1,776.2)\end{array}$ & $\begin{array}{l}-140.1 \\
(541.7)\end{array}$ & $\begin{array}{c}- \\
6,570.7^{* * *} \\
(2,435.1)\end{array}$ \\
\hline Public information $\times$ Price regressor & $\begin{array}{c}602.4^{* *} \\
(287.9)\end{array}$ & $\begin{array}{c}663.5 \\
(413.2)\end{array}$ & $\begin{array}{c}145.2 \\
(200.6)\end{array}$ & $\begin{array}{c}1,599.8^{* * *} \\
(563.6)\end{array}$ \\
\hline Land & $\begin{array}{c}2,186.8^{* * *} \\
(181.7)\end{array}$ & $\begin{array}{c}2,198.2^{* * * *} \\
(178.2)\end{array}$ & $\begin{array}{c}2,253.3^{* * *} * \\
(162.3)\end{array}$ & $\begin{array}{c}2,463.8^{* * *} \\
(405.4)\end{array}$ \\
\hline Constant & $\begin{array}{c}2,794.0^{* *} \\
(1,078.8)\end{array}$ & $\begin{array}{c}3,084.0^{* * *} \\
(423.0)\end{array}$ & $\begin{array}{c}3,158.3^{* * *} \\
(558.0)\end{array}$ & $\begin{array}{c}6,241.7^{* * *} \\
(2,060.1)\end{array}$ \\
\hline Observations & 2,300 & 2,317 & 2,283 & 443 \\
\hline$R$-squared & 0.392 & 0.390 & 0.362 & 0.515 \\
\hline Mean DV & 3872 & 3859 & 5019 & 3780 \\
\hline SE DV & 214.9 & 213.5 & 172.9 & 437.1 \\
\hline
\end{tabular}

An observation records the total quantity of potatoes of a particular variety and quality sold by an individual farmer over the whole year. A mandi is defined as a (physical) market-variety combination. Columns differ in the definition of the price regressor. In column 1 it is the relevant mandi price averaged over the weeks when the farmer sold potatoes of that variety. In column 2 it is the relevant mandi price averaged over all weeks in the year, with each week weighted in proportion to the quantity sold that week by sample farmers in control villages in that district. In column 3 it is the average deviation of the relevant mandi price in 2008 from the predicted mandi price for 2008, where the prediction is from a linear regression of weekly mandi prices for 2007, 2011 and 2012 on mandi dummies, period dummies, year dummies and their interactions. In column 4 the sample is restricted to farmers who likely were in long-term relationships with buyers, as assessed from their reports in 2010 of selling to a buyer whom they had been selling to for longer than 5 years. The price regressor in column 4 is the same as in column 1 . All columns include dummies for the quality of potatoes sold, and column 3 also includes dummies for the potato variety. Columns $1,2 \& 4$ include dummies for the mandi whose catchment area the farmer resides in. Standard errors in parentheses are clustered at the village level in columns 1 , 2 and 4 , and are village-cluster bootstrapped in column $3 .^{* * *}: p<0.01,{ }^{* *}: p<0.05,{ }^{*}: p<0.1$. 
Table 7: Heterogeneous Impacts of Interventions on Net Farm Revenue

\begin{tabular}{|c|c|c|c|c|}
\hline & $\begin{array}{c}\text { Farmer- } \\
\text { specific } \\
\text { average } \\
(1)\end{array}$ & $\begin{array}{c}\text { Weighted } \\
\text { average } \\
\text { (2) }\end{array}$ & $\begin{array}{l}\text { Deviation } \\
\text { from } \\
\text { expected } \\
\text { mandi } \\
\text { price } \\
(3)\end{array}$ & $\begin{array}{c}\text { Long-term } \\
\text { relation- } \\
\text { ships } \\
(4)\end{array}$ \\
\hline Price regressor & $\begin{array}{c}608.1 \\
(508.5)\end{array}$ & & $\begin{array}{c}-362.9^{*} \\
(207.4)\end{array}$ & $\begin{array}{c}-261.7 \\
(1,046.2)\end{array}$ \\
\hline Private information & $\begin{array}{c}-8,041.6^{* *} \\
(3,326.0)\end{array}$ & $\begin{array}{c}-9,117.1^{* *} \\
(4,427.9)\end{array}$ & $\begin{array}{c}1,539.7 \\
(1,491.8)\end{array}$ & $\begin{array}{c}-8,542.9 \\
(6,237.7)\end{array}$ \\
\hline Private information $\times$ Price regressor & $\begin{array}{c}1,867.1^{* *} \\
(705.6)\end{array}$ & $\begin{array}{c}2,197.0^{* *} \\
(993.3)\end{array}$ & $\begin{array}{c}1,966.4^{* *} \\
(776.4)\end{array}$ & $\begin{array}{c}2,023.3 \\
(1,557.2)\end{array}$ \\
\hline Phone & $\begin{array}{c}4,237.4 \\
(3,261.7)\end{array}$ & $\begin{array}{c}1,248.1 \\
(3,463.4)\end{array}$ & $\begin{array}{c}378.6 \\
(1,258.4)\end{array}$ & $\begin{array}{c}8,450.7 \\
(6,191.7)\end{array}$ \\
\hline Phone $\times$ Price regressor & $\begin{array}{l}-888.1 \\
(740.7)\end{array}$ & $\begin{array}{l}-174.7 \\
(845.5)\end{array}$ & $\begin{array}{l}-407.3 \\
(767.7)\end{array}$ & $\begin{array}{c}-1,842.9 \\
(1,525.9)\end{array}$ \\
\hline Public information & $\begin{array}{c}-6,928.1^{* *} \\
(3,216.7)\end{array}$ & $\begin{array}{c}-7,519.9 \\
(4,525.2)\end{array}$ & $\begin{array}{c}-750.1 \\
(1,220.6)\end{array}$ & $\begin{array}{c}-9,271.0 \\
(5,676.4)\end{array}$ \\
\hline Public information $\times$ Price regressor & $\begin{array}{c}1,393.6^{* *} \\
(689.2)\end{array}$ & $\begin{array}{l}1,529.8 \\
(993.4)\end{array}$ & $\begin{array}{c}27.8 \\
(487.5)\end{array}$ & $\begin{array}{c}2,354.7^{*} \\
(1,407.3)\end{array}$ \\
\hline Land & $\begin{array}{c}3,892.7^{* * *} \\
(348.0)\end{array}$ & $\begin{array}{c}3,924.6^{* * *} \\
(338.3)\end{array}$ & $\begin{array}{c}4,079.6^{* * *} \\
(321.4)\end{array}$ & $\begin{array}{c}4,494.3^{* * *} \\
(722.4)\end{array}$ \\
\hline Constant & $\begin{array}{c}4,347.7^{*} \\
(2,540.2)\end{array}$ & $\begin{array}{c}6,937.5^{* * *} \\
(955.2)\end{array}$ & $\begin{array}{c}6,871.0^{* * *} \\
(1,333.7)\end{array}$ & $\begin{array}{c}7,820.6^{*} \\
(4,549.9)\end{array}$ \\
\hline Observations & 2,300 & 2,317 & 2,283 & 443 \\
\hline$R$-squared & 0.370 & 0.364 & 0.335 & 0.487 \\
\hline Mean DV & 7845 & 7825 & 10348 & 8349 \\
\hline SE DV & 406.5 & 404.0 & 326.1 & 987.5 \\
\hline
\end{tabular}

Notes below Table 6 apply. The dependent variable is the net revenue from potato sales earned by the farmer over the year, computed by subtracting transport, handling and storage costs incurred by the farmer from the gross revenue he received from buyers over the year. 
Table 8: Farmer Sales at the Market (Haat)

\begin{tabular}{|c|c|c|c|c|}
\hline & $\begin{array}{l}\text { Gross } \\
\text { price } \\
\text { received } \\
\quad(1)\end{array}$ & $(2)$ & $\begin{array}{l}\text { Sold at haat } \\
\qquad(3)\end{array}$ & (4) \\
\hline Sold at haat & $\begin{array}{c}0.361^{*} \\
(0.178)\end{array}$ & & & \\
\hline Mandi price & $\begin{array}{c}0.233^{* * *} \\
(0.054)\end{array}$ & $\begin{array}{c}0.809^{* * *} \\
(0.143)\end{array}$ & $\begin{array}{c}0.470^{* * *} \\
(0.096)\end{array}$ & $\begin{array}{c}0.411^{* * *} \\
(0.105)\end{array}$ \\
\hline Distance to mandi & & & & $\begin{array}{c}0.226^{* * *} \\
(0.069)\end{array}$ \\
\hline Medinipur & $\begin{array}{r}-0.296^{*} \\
(0.167)\end{array}$ & & $\begin{array}{l}1.562^{*} \\
(0.890)\end{array}$ & $\begin{array}{l}1.391 \\
(0.883)\end{array}$ \\
\hline Land & $\begin{array}{c}-0.058^{* * *} \\
(0.013)\end{array}$ & $\begin{array}{l}-0.028 \\
(0.063)\end{array}$ & $\begin{array}{l}-0.070 \\
(0.066)\end{array}$ & $\begin{array}{l}-0.034 \\
(0.083)\end{array}$ \\
\hline Constant & $\begin{array}{c}1.458^{* * *} \\
(0.185)\end{array}$ & $\begin{array}{c}-6.253^{* * *} \\
(0.831)\end{array}$ & $\begin{array}{l}-5.716^{* * *} \\
(0.947)\end{array}$ & $\begin{array}{c}-5.713^{* * *} \\
(0.936)\end{array}$ \\
\hline $\begin{array}{l}\text { Observations } \\
R \text {-squared/Pseudo R-squared }\end{array}$ & $\begin{array}{l}3,914 \\
0.368\end{array}$ & $\begin{array}{l}3,914 \\
0.181\end{array}$ & $\begin{array}{l}3,914 \\
0.202\end{array}$ & $\begin{array}{l}3,680 \\
0.257\end{array}$ \\
\hline $\begin{array}{l}\text { Mean DV } \\
\text { SE DV }\end{array}$ & $\begin{array}{l}2.247 \\
0.012\end{array}$ & $\begin{array}{l}0.024 \\
0.001\end{array}$ & $\begin{array}{l}0.024 \\
0.001\end{array}$ & $\begin{array}{l}0.024 \\
0.001\end{array}$ \\
\hline
\end{tabular}

Each observation corresponds to a farmer-variety-quality-week combination. Variety and quality dummies are included. In column 1 the dependent variable is the gross price per $\mathrm{kg}$ received for potatoes sold. In columns 2-4 it is a binary variable indicating whether the farmer sold potatoes at the haat and a logit specification is used, with odds-ratios and the psuedo R-squared reported. Robust standard errors are in parentheses. $^{* * *}: p<0.01,{ }^{* *}: p<0.05,{ }^{*}: p<0.1$. 


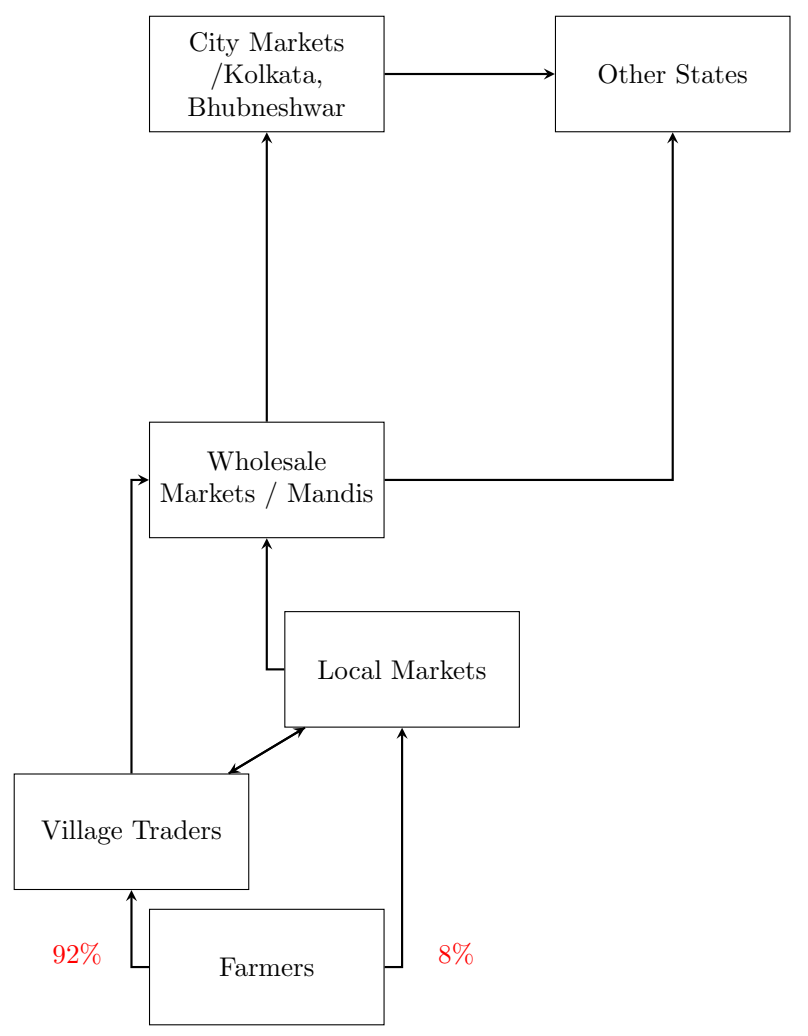

Figure 1: Potato Supply Chain

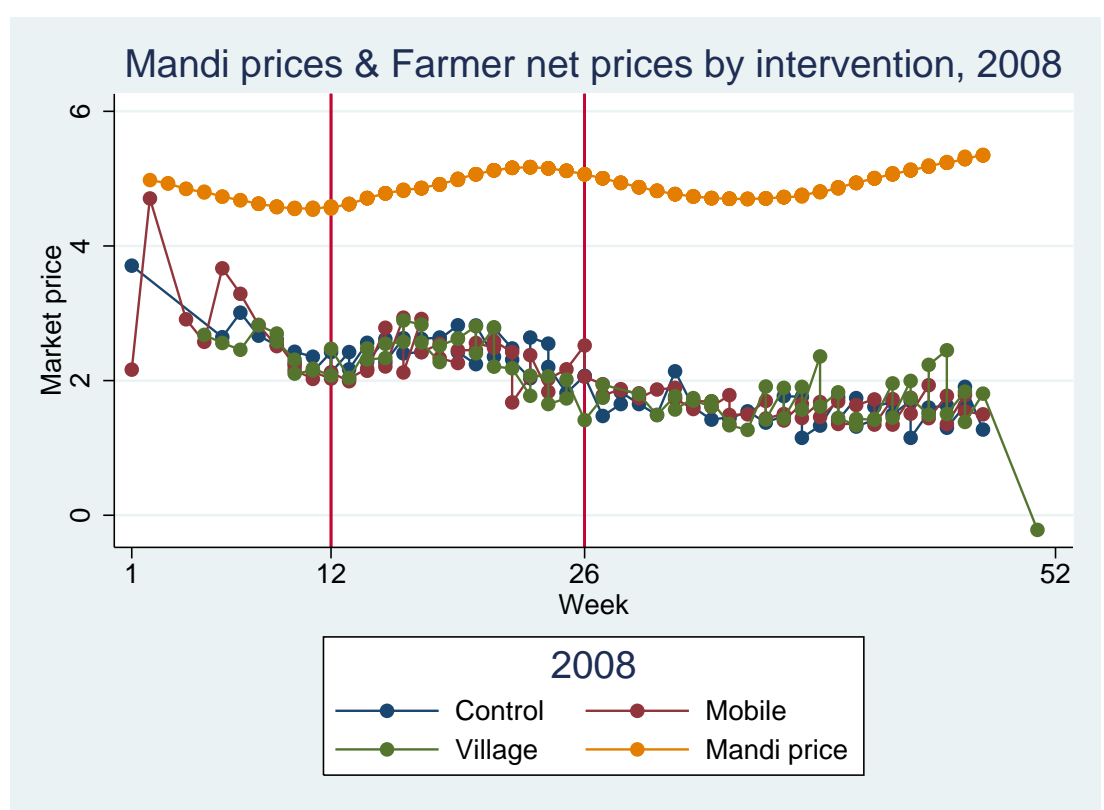

Figure 2: Intervention Impacts 


\section{Asymmetric Information and Middleman Margins: An Experiment with Indian Potato Farmers}

\section{A Theory Appendix}

Notation and Technical Assumptions: (i) $u$ is strictly concave, satisfying Inada conditions, and the property that $\frac{q^{\prime *}(p)}{q^{*}(p)}$ is non-increasing in $p$, where $q^{*}(p)$ denotes the farmer's supply function, i.e., the solution to $q$ in maximizing $p q-u(\bar{q}-q)$. This insures that the monopsonist's marginal cost $p(q)+q p^{\prime}(q)$ of procuring quantity $q$ is increasing in $q$, where $p(q)$ is the inverse of $q^{*}(p)$. (ii) F's information about $\nu$ is represented by a c.d.f. $\mathrm{G}(\nu)$ with full support over $[\underline{v}, \infty)$.

The Separating Equilibrium: Working backwards from Stage 5, suppose F had taken $q_{2}$ to the mandi and received a price offer of $m$ from MT. To determine the quantity to sell at this price, he selects $q \leq q_{2}$ to maximize $m q-t\left(q_{2}-q\right)+u(\bar{q}-q)$. The "effective" price he receives is now $m+t$, since anything not sold here will have to be transported back at an additional cost of $t$. The solution to this is $q\left(q_{2}, m\right)=q^{*}(m+t)$ if $q_{2} \geq q^{*}(m+t)$, and $q_{2}$ otherwise. Note that the farmer's beliefs regarding $\nu$ do not matter here, since the only option he has at this stage is to either sell to MT at the offered price $m$ or consume the rest.

In Stage 4, MT is approached by F with stock $q_{2}$. Let $n\left(q_{2}\right)$ be defined by the solution to $m$ in $q^{*}(m+t)=q_{2}$. Any price $m$ bigger than $n\left(q_{2}\right)$ is dominated by the price $n\left(q_{2}\right)$ since it would result in the same traded volume $q_{2}$ but at a higher price. Any price $m$ lower than $n\left(q_{2}\right)$ will result in traded volume of $q^{*}(m+t)$ at price $m$. Hence MT selects a price $m\left(\nu ; q_{2}, t\right) \leq n\left(q_{2}\right)$ to maximize $(\nu-m) q^{*}(m+t)$. If we assume $\frac{q^{*}}{q^{* \prime}}$ is nondecreasing, then this is a concave maximization problem. Hence MT will offer a price $m\left(\nu ; q_{2}, t\right) \equiv \min \left\{n\left(q_{2}\right), m(\nu)\right\}$.

Moving back to Stage 3, suppose that F has decided to reject VT's offer. Here his beliefs about $\nu$ affect what he expects MT to offer at Stage 4. Suppose that F believes that the realization of $\nu$ is $\tilde{\nu}$ with probability one. A choice of $q_{2} \leq q^{*}(m(\tilde{\nu})+t)$ will result in a sale of $q_{2}$ to MT at a price of $n\left(q_{2}\right)$, and a payoff of

$$
\mathcal{P}\left(q_{2}, \tilde{\nu}\right) \equiv n\left(q_{2}\right) q_{2}+u\left(\bar{q}-q_{2}\right)-t q_{2} .
$$


Given the definition of the function $n(\cdot)$, it follows that $\mathcal{P}\left(q_{2}, \tilde{\nu}\right)$ is (locally) strictly increasing in $q_{2}$. Hence any $q_{2}<q^{*}(m(\tilde{\nu})+t)$ is strictly dominated by $q_{2}=q^{*}(m(\tilde{\nu})+t)$.

Now consider any $q_{2}>q^{*}(m(\tilde{\nu})+t)$. This will lead to a sale of $q^{*}(m(\tilde{\nu})+t)$ to MT at a price of $m(\tilde{\nu})$, with the excess transported back to the village. Hence it is optimal for $\mathrm{F}$ to select $q_{2}=q^{*}(m(\tilde{\nu})+t)$ if he rejects VT's offer. In this event his payoff from the resulting continuation game will be

$$
[m(\tilde{\nu})-t] q^{*}(m(\tilde{\nu})+t)+u\left(\bar{q}-q^{*}(m(\tilde{\nu})+t)\right)
$$

At Stage 2 , then, if VT offers a price $p(\tilde{\nu})$ where $\tilde{\nu} \geq \underline{v}$, the farmer believes the realization of $\nu$ is $\tilde{\nu}$ with probability one and expects a payoff equal to (3) if he rejects the offer. The farmer is indifferent between accepting and rejecting the offer, by construction of the function $p(\tilde{\nu})$. Hence it is optimal for the farmer to randomize between accepting and rejecting the offer; in the event of accepting $\mathrm{F}$ will sell $q^{*}(p(\tilde{\nu}))$ to TV. And offering any price less than $p(\underline{v})$ leads the farmer to believe that $\tilde{\nu}=\underline{v}$ with probability one, so such an offer will surely be rejected.

Finally consider VT's problem of deciding what price to offer at Stage 1. Any offer below $p(\underline{v})$ will surely be rejected, while any offer $p(\tilde{\nu}), \tilde{\nu} \geq \underline{v}$ will be accepted with probability $1-\alpha(\tilde{\nu})$ and will result in a trade of $q^{*}(p(\tilde{\nu}))$ at price $p(\tilde{\nu})$. Hence VT's problem is similar to making a price report of $\tilde{\nu} \geq \underline{v}$ in a revelation mechanism which results in a trade of $q^{*}(p(\tilde{\nu}))$ at price $p(\tilde{\nu})$, resulting in a payoff of

$$
\mathcal{W}(\tilde{\nu} \mid \nu)=[1-\alpha(\tilde{\nu})][\nu-p(\tilde{\nu})] q^{*}(p(\tilde{\nu}))
$$

It remains to check that it is optimal for VT to report truthfully in this revelation mechanism. Now $\mathcal{W}_{\nu}(\tilde{\nu} \mid \nu)=[1-\alpha(\tilde{\nu})] q^{*}(\tilde{\nu})$, so if we define $X(\nu)=\mathcal{W}(\nu \mid \nu)$ we see that incentive compatibility requires that locally $X^{\prime}(\nu)=[1-\alpha(\nu)] q^{*}(p(\nu))$, i.e.,

$$
X(\nu)=X(\underline{v})+\int_{\underline{v}}^{\nu}[1-\alpha(\tilde{\nu})] q^{*}(p(\tilde{\nu})) d \tilde{\nu}
$$

which implies that

$$
[1-\alpha(\nu)][\nu-p(\nu)] q^{*}(p(\nu))=[1-\alpha(\underline{v})][\nu-p(\underline{v})] q^{*}(p(\underline{v}))+\int_{\underline{v}}^{\nu}[1-\alpha(\tilde{\nu})] q^{*}(p(\tilde{\nu})) d \tilde{\nu}
$$

Differentiating with respect to $\nu$, this local incentive compatibility condition reduces to the dif- 
ferential equation

$$
\frac{\alpha^{\prime}(\nu)}{\alpha(\nu)}=\left[\frac{q^{* \prime}(p(\nu))}{q^{*}(p(\nu))}-\frac{1}{\nu-p(\nu)}\right] p^{\prime}(\nu)
$$

with endpoint condition $\alpha(\underline{v})=\bar{\alpha}$ for arbitrary $\bar{\alpha} \in(0,1)$.

A sufficient condition for global incentive compatibility (see Mirrlees (1986)) is that $\mathcal{W}_{\nu}(\tilde{\nu} \mid \nu)=[1-\alpha(\tilde{\nu})] q^{*}(p(\tilde{\nu}))$ is non-decreasing in $\tilde{\nu}$. This is equivalent to $-\alpha^{\prime}(\nu) q^{*}(p(\nu))+[1-$ $\alpha(\nu)] q^{*^{\prime}}(p(\nu)) p^{\prime}(\nu) \geq 0$ for all $\nu$. Condition (7) implies $-\alpha^{\prime}(\tilde{\nu}) q^{*}(p(\tilde{\nu}))+[1-\alpha(\nu)] q^{*^{\prime}}(p(\nu)) p^{\prime}(\nu)=$ $\frac{[1-\alpha(\nu)] p^{\prime}(\nu) q^{*}(p(\nu))}{\nu-p(\nu)}>0$.

That $p(\nu)<m(\nu)$ is obvious from the definition of $p(\nu)$. The unconstrained monopsony price $p$ for VT (which maximizes $\left.(\nu-p) q^{*}(p)\right)$ exceeds $m(\nu)$, since the former solves $p+\frac{q^{*}(p)}{q^{*^{\prime}}(p)}=\nu$ while the latter solves $m+\frac{q^{*}(m+t)}{q^{*^{\prime}}(m+t)}=\nu$, and $\frac{q^{*}}{q^{*}}$ is non-decreasing. Hence the monopsony price exceeds $p(\nu)$, implying that $\frac{q^{*^{\prime}}(p(\nu))}{q^{*}(p(\nu))}>\frac{1}{\nu-p(\nu)}$, so $\alpha(\nu)$ is strictly increasing.

Pooling Equilibria: Note first that nothing changes from the separating equilibrium above at Stages 4 and 5 , since the farmer's beliefs do not matter at these stages.

At Stage 3, the farmer's beliefs do affect his decision on the stock $q_{2}$ to take to the mandi upon rejecting VT's offer. Suppose that the farmer's updated beliefs at Stage 3 are obtained by conditioning on the event that $\nu \in\left[\nu^{*}, \nu^{*}+x\right]$ where $\nu^{*} \geq \underline{v}$ and $x>0$. F will then not be able to exactly forecast the price that MT will offer him at Stage 4 . He knows that if he takes $q_{2}$, and the state happens to be $\nu$, MT will offer him a price $M\left(\nu ; q_{2}, t\right)=\min \left\{n\left(q_{2}\right), m(\nu)\right\}$, that he will then sell MT a quantity $Q_{2}\left(\nu ; q_{2}, t\right)=\min \left\{q_{2}, q^{*}\left(M\left(\nu ; q_{2}, t\right)+t\right)\right\}$, and carry the rest back to the village. Since $m(\nu)$ is increasing in $\nu$, his ex post payoff will be increasing in $\nu$ for any given $q_{2}$. Moreover, given any $\nu^{*}$, an increase in $x$ will induce him to select a higher optimal $q_{2}$ and earn a strictly higher continuation payoff from rejecting VT's offer. Denote this payoff by $Y\left(\nu^{*}, x\right)$, which is thereby strictly increasing in $x$. It is evident that $Y\left(\nu^{*}, 0\right)$ is the expected payoff when he is certain the state is $\nu^{*}$, as in the separating equilibrium in state $\nu^{*}$. Hence $Y\left(\nu^{*}, 0\right)=\Pi\left(p\left(\nu^{*}\right)\right)$, the payoff attained by $\mathrm{F}$ in the separating equilibrium in state $\nu^{*}$.

Construct the endpoints $\left\{\nu_{i}\right\}$ of the partition and the prices $\left\{r_{i}\right\}$ iteratively as follows. Define the function $\tilde{p}\left(\nu^{*}, x\right)$ by the property that $\Pi\left(\tilde{p}\left(\nu^{*}, x\right)\right)=Y\left(\nu^{*}, x\right)$, the price which if offered by VT would make F indifferent between accepting and rejecting, conditional on knowing that $\nu \in\left[\nu^{*}, \nu^{*}+x\right]$. By definition, then, $\tilde{p}\left(\nu^{*}, 0\right)=p\left(\nu^{*}\right)$. Select $\nu_{0}=\underline{v}$. Given $\nu_{i-1}$, select $r_{i} \in$ 
$\left(p\left(\nu_{i-1}\right), \tilde{p}\left(\nu_{i-1}, \infty\right)\right)$. Select $\nu_{i}=\nu_{i-1}+x_{i}$ where $x_{i}$ is defined by the property that $\tilde{p}\left(\nu_{i}, x_{i}\right)=r_{i}$. By construction, $\mathrm{F}$ is indifferent between accepting and rejecting a price offer of $r_{i}$ from TV, conditional on the information that $\nu \in\left[\nu_{i-1}, \nu_{i}\right]$.

The rest of the argument is straightforward. VT in state $\nu_{i-1}$ is indifferent between offering prices $r_{i-1}$ and $r_{i}$. This implies that in any state $\nu \in\left[\nu_{i-2}, \nu_{i-1}\right)$, he prefers to offer $r_{i-1}$ rather than $r_{i}$. Moreover, the single-crossing property of VT's payoffs with respect to the state $\nu$ implies that each type is selecting offers optimally in the set $\left\{r_{i}\right\}_{i=1,2, . .}$. Also offering a price between $r_{i-1}$ and $r_{i}$ is dominated by the price $r_{i}$, since it corresponds to the same probability of acceptance by F, and a lower profit for VT conditional on acceptance.

\section{B Additional Figures}




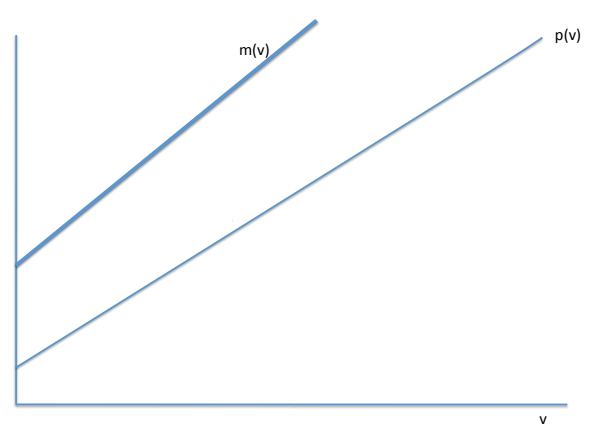

(a) Separating Equilibrium

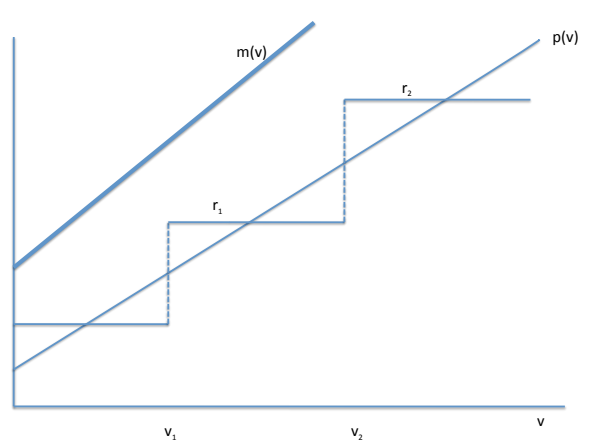

(b) Partially Pooling Equilibrium

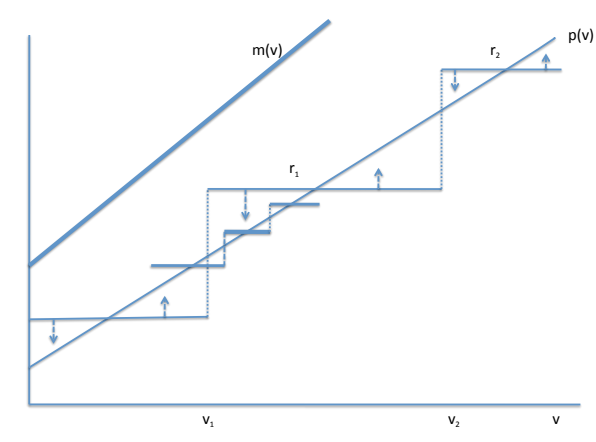

(c) Effect of the Information Treatment

Figure B1: Equilibria and Treatment Effects in the Ex post Bargaining Model 


\section{Additional Tables}

Table C1: Baseline Characteristics of Sample Villages and Households

\begin{tabular}{|c|c|c|c|c|c|c|c|}
\hline & $\begin{array}{c}\text { Total } \\
(1) \\
\end{array}$ & $\begin{array}{c}\text { Control } \\
(2) \\
\end{array}$ & $\begin{array}{c}\text { Private } \\
\text { info. } \\
(3) \\
\end{array}$ & $\begin{array}{c}\text { Public in- } \\
\text { formation } \\
\quad(4)\end{array}$ & $\begin{array}{c}\text { Public v. } \\
\text { Control } \\
(4)-(2) \\
\end{array}$ & $\begin{array}{c}\text { Private v. } \\
\text { Control } \\
(3)-(2) \\
\end{array}$ & $\begin{array}{c}\text { Public v. } \\
\text { Private } \\
(4)-(3)\end{array}$ \\
\hline \multicolumn{8}{|c|}{ Panel A: Village Characteristics } \\
\hline Distance to mandi (km) & $\begin{array}{c}8.52 \\
(0.700)\end{array}$ & $\begin{array}{c}8.93 \\
(0.882)\end{array}$ & $\begin{array}{l}8.558 \\
(1.648)\end{array}$ & $\begin{array}{c}8.071 \\
(1.014)\end{array}$ & $\begin{array}{r}-0.859 \\
0.526\end{array}$ & $\begin{array}{r}-0.372 \\
0.843\end{array}$ & $\begin{array}{r}-0.487 \\
0.802\end{array}$ \\
\hline Public telephone & $\begin{array}{c}0.514 \\
(0.059)\end{array}$ & $\begin{array}{c}0.667 \\
(0.098)\end{array}$ & $\begin{array}{c}0.417 \\
(0.103)\end{array}$ & $\begin{array}{c}0.458 \\
(0.104)\end{array}$ & $\begin{array}{r}-0.208 \\
0.152\end{array}$ & $\begin{array}{c}-0.250^{*} \\
0.085\end{array}$ & $\begin{array}{l}0.042 \\
0.777\end{array}$ \\
\hline Factory/mill & $\begin{array}{c}0.556 \\
(0.059)\end{array}$ & $\begin{array}{l}0.458 \\
(0.104)\end{array}$ & $\begin{array}{c}0.667 \\
(0.098)\end{array}$ & $\begin{array}{c}0.542 \\
(0.104)\end{array}$ & $\begin{array}{l}0.083 \\
0.573\end{array}$ & $\begin{array}{l}0.208 \\
0.152\end{array}$ & $\begin{array}{l}-0.125 \\
0.387\end{array}$ \\
\hline Metalled road & $\begin{array}{c}0.361 \\
(0.057)\end{array}$ & $\begin{array}{c}0.250 \\
(0.090)\end{array}$ & $\begin{array}{c}0.458 \\
(0.104)\end{array}$ & $\begin{array}{c}0.375 \\
(0.101)\end{array}$ & $\begin{array}{l}0.125 \\
0.361\end{array}$ & $\begin{array}{l}0.208 \\
0.137\end{array}$ & $\begin{array}{c}-0.083 \\
0.568\end{array}$ \\
\hline \multicolumn{8}{|c|}{ Panel B: Household Characteristics } \\
\hline Land owned (acres) & $\begin{array}{c}1.114 \\
(0.0305)\end{array}$ & $\begin{array}{c}1.123 \\
(0.0497)\end{array}$ & $\begin{array}{c}1.079 \\
(0.0503)\end{array}$ & $\begin{array}{c}1.144 \\
(0.0584)\end{array}$ & $\begin{array}{l}0.021 \\
0.889\end{array}$ & $\begin{array}{r}-0.045 \\
0.675\end{array}$ & $\begin{array}{l}0.065 \\
0.653\end{array}$ \\
\hline Cultivator's age (yrs) & $\begin{array}{c}48.84 \\
(0.404)\end{array}$ & $\begin{array}{c}49.5 \\
(0.682)\end{array}$ & $\begin{array}{c}48.92 \\
(0.682)\end{array}$ & $\begin{array}{c}48.05 \\
(0.737)\end{array}$ & $\begin{array}{l}-1.451 \\
0.304\end{array}$ & $\begin{array}{r}-0.577 \\
0.644\end{array}$ & $\begin{array}{r}-0.874 \\
0.385\end{array}$ \\
\hline Cultivator's schooling (yrs) & $\begin{array}{c}6.989 \\
(0.116)\end{array}$ & $\begin{array}{c}6.597 \\
(0.204)\end{array}$ & $\begin{array}{c}7.01 \\
(0.201)\end{array}$ & $\begin{array}{c}7.4 \\
(0.192)\end{array}$ & $\begin{array}{l}0.803 \\
0.062\end{array}$ & $\begin{array}{l}0.413 \\
0.356\end{array}$ & $\begin{array}{c}0.39 \\
0.333\end{array}$ \\
\hline \multicolumn{8}{|l|}{ Panel C: Potato Cultivation } \\
\hline Planted potatoes & $\begin{array}{c}0.995 \\
(0.002)\end{array}$ & $\begin{array}{c}0.987 \\
(0.005)\end{array}$ & $\begin{array}{c}0.998 \\
(0.002)\end{array}$ & $\begin{array}{l}1.00 \\
(0.00)\end{array}$ & $\begin{array}{c}0.013^{* *} \\
0.047\end{array}$ & $\begin{array}{c}0.011^{*} \\
0.099\end{array}$ & $\begin{array}{l}0.002 \\
0.316\end{array}$ \\
\hline Planted jyoti & $\begin{array}{c}0.935 \\
(0.006)\end{array}$ & $\begin{array}{c}0.949 \\
(0.010)\end{array}$ & $\begin{array}{c}0.954 \\
(0.009)\end{array}$ & $\begin{array}{c}0.901 \\
(0.013)\end{array}$ & $\begin{array}{r}-0.048 \\
0.195\end{array}$ & $\begin{array}{l}0.005 \\
0.844\end{array}$ & $\begin{array}{l}-0.053 \\
0.172\end{array}$ \\
\hline Planted $c^{\prime} m u k h i$ & $\begin{array}{c}0.096 \\
(0.007)\end{array}$ & $\begin{array}{c}0.051 \\
(0.010)\end{array}$ & $\begin{array}{c}0.111 \\
(0.014)\end{array}$ & $\begin{array}{c}0.126 \\
(0.015)\end{array}$ & $\begin{array}{l}0.076 \\
0.123\end{array}$ & $\begin{array}{l}0.06 \\
0.192\end{array}$ & $\begin{array}{l}0.016 \\
0.763\end{array}$ \\
\hline Area planted (acres) & $\begin{array}{c}0.904 \\
(0.058)\end{array}$ & $\begin{array}{c}0.822 \\
(0.087)\end{array}$ & $\begin{array}{c}0.851 \\
(0.048)\end{array}$ & $\begin{array}{l}1.051 \\
(0.151)\end{array}$ & $\begin{array}{l}0.229 \\
0.243\end{array}$ & $\begin{array}{l}0.029 \\
0.833\end{array}$ & $\begin{array}{l}0.2 \\
0.27\end{array}$ \\
\hline Harvest (kg) & $\begin{array}{l}7056.3 \\
(224.5)\end{array}$ & $\begin{array}{l}6396.6 \\
(282.7)\end{array}$ & $\begin{array}{l}7186.7 \\
(376.7)\end{array}$ & $\begin{array}{l}7641.4 \\
(496.8)\end{array}$ & $\begin{array}{c}1244.84 \\
0.429\end{array}$ & $\begin{array}{l}790.14 \\
0.432\end{array}$ & $\begin{array}{c}454.70 \\
0.778\end{array}$ \\
\hline Fraction of harvest sold & $\begin{array}{c}0.798 \\
(0.006)\end{array}$ & $\begin{array}{c}0.811 \\
(0.009)\end{array}$ & $\begin{array}{c}0.783 \\
(0.010)\end{array}$ & $\begin{array}{c}0.801 \\
(0.010)\end{array}$ & $\begin{array}{l}-0.01 \\
0.764\end{array}$ & $\begin{array}{c}-0.028 \\
0.4\end{array}$ & $\begin{array}{l}0.018 \\
0.601\end{array}$ \\
\hline Average price & $\begin{array}{c}3.935 \\
(0.023)\end{array}$ & $\begin{array}{c}3.879 \\
(0.036)\end{array}$ & $\begin{array}{c}3.844 \\
(0.040)\end{array}$ & $\begin{array}{c}4.093 \\
(0.039)\end{array}$ & $\begin{array}{l}0.214 \\
0.126\end{array}$ & $\begin{array}{l}-0.035 \\
0.832\end{array}$ & $\begin{array}{c}0.249^{*} \\
0.094\end{array}$ \\
\hline Frac. sold to trader & $\begin{array}{c}0.986 \\
(0.003)\end{array}$ & $\begin{array}{c}0.989 \\
(0.005)\end{array}$ & $\begin{array}{c}0.986 \\
(0.005)\end{array}$ & $\begin{array}{c}0.984 \\
(0.006)\end{array}$ & $\begin{array}{c}-0.005 \\
0.62\end{array}$ & $\begin{array}{c}-0.002 \\
0.766\end{array}$ & $\begin{array}{c}-0.003 \\
0.781\end{array}$ \\
\hline Frac. sold at market & $\begin{array}{c}0.008 \\
(0.002)\end{array}$ & $\begin{array}{c}0.006 \\
(0.004)\end{array}$ & $\begin{array}{c}0.01 \\
(0.005)\end{array}$ & $\begin{array}{c}0.009 \\
(0.004)\end{array}$ & $\begin{array}{l}0.003 \\
0.725\end{array}$ & $\begin{array}{l}0.004 \\
0.498\end{array}$ & $\begin{array}{r}-0.001 \\
0.846\end{array}$ \\
\hline \multicolumn{8}{|l|}{ Panel D: Telecommunications } \\
\hline Has landline phone & 0.238 & 0.231 & 0.23 & 0.254 & 0.023 & $\begin{array}{c}-0.001 \\
\text { ontinued on }\end{array}$ & $\begin{array}{c}0.023 \\
\text { next page }\end{array}$ \\
\hline
\end{tabular}


Table C1 - Continued

\begin{tabular}{|c|c|c|c|c|c|c|c|}
\hline & $\begin{array}{l}\text { Total } \\
(1) \\
\end{array}$ & $\begin{array}{c}\text { Control } \\
(2) \\
\end{array}$ & $\begin{array}{l}\text { Private in- } \\
\text { formation } \\
(3)\end{array}$ & $\begin{array}{l}\text { Public in- } \\
\text { formation } \\
\quad(4)\end{array}$ & $\begin{array}{c}\text { Public v. } \\
\text { Control } \\
(4)-(2) \\
\end{array}$ & $\begin{array}{c}\text { Private v. } \\
\text { Control } \\
(3)-(2) \\
\end{array}$ & $\begin{array}{r}\text { Public v } \\
\text { Private } \\
(4)-(3) \\
\end{array}$ \\
\hline Has cellphone & $\begin{array}{c}(0.011) \\
0.332 \\
(0.012)\end{array}$ & $\begin{array}{c}(0.019) \\
0.323 \\
(0.021)\end{array}$ & $\begin{array}{c}(0.019) \\
0.316 \\
(0.021)\end{array}$ & $\begin{array}{c}(0.020) \\
0.361 \\
(0.023)\end{array}$ & $\begin{array}{c}0.797 \\
0.039 \\
0.65\end{array}$ & $\begin{array}{c}0.992 \\
-0.006 \\
0.941\end{array}$ & $\begin{array}{l}0.77 / 4 \\
0.045 \\
0.551\end{array}$ \\
\hline Panel E: Source of Price Information & & & & & & & \\
\hline Trader & $\begin{array}{c}0.712 \\
(0.012)\end{array}$ & $\begin{array}{c}0.795 \\
(0.018)\end{array}$ & $\begin{array}{c}0.68 \\
(0.021)\end{array}$ & $\begin{array}{c}0.659 \\
(0.022)\end{array}$ & $\begin{array}{c}-0.136^{*} \\
0.064\end{array}$ & $\begin{array}{c}-0.115 \\
0.172\end{array}$ & $\begin{array}{r}-0.021 \\
0.804\end{array}$ \\
\hline Only trader & $\begin{array}{c}0.455 \\
(0.013)\end{array}$ & $\begin{array}{c}0.487 \\
(0.023)\end{array}$ & $\begin{array}{c}0.443 \\
(0.022)\end{array}$ & $\begin{array}{c}0.434 \\
(0.023)\end{array}$ & $\begin{array}{c}-0.053 \\
0.525\end{array}$ & $\begin{array}{r}-0.043 \\
0.663\end{array}$ & $\begin{array}{c}-0.009 \\
0.916\end{array}$ \\
\hline Market & $\begin{array}{c}0.177 \\
(0.010)\end{array}$ & $\begin{array}{c}0.148 \\
(0.016)\end{array}$ & $\begin{array}{c}0.186 \\
(0.017)\end{array}$ & $\begin{array}{c}0.197 \\
(0.019)\end{array}$ & $\begin{array}{c}0.049 \\
0.48\end{array}$ & $\begin{array}{c}0.037 \\
0.61\end{array}$ & $\begin{array}{l}0.012 \\
0.876\end{array}$ \\
\hline Friends & $\begin{array}{c}0.131 \\
(0.009)\end{array}$ & $\begin{array}{c}0.15 \\
(0.016)\end{array}$ & $\begin{array}{c}0.141 \\
(0.015)\end{array}$ & $\begin{array}{c}0.101 \\
(0.014)\end{array}$ & $\begin{array}{c}-0.049 \\
0.34\end{array}$ & $\begin{array}{c}-0.009 \\
0.89\end{array}$ & $\begin{array}{l}-0.04 \\
0.525\end{array}$ \\
\hline Media & $\begin{array}{c}0.06 \\
(0.006)\end{array}$ & $\begin{array}{c}0.081 \\
(0.012)\end{array}$ & $\begin{array}{c}0.055 \\
(0.010)\end{array}$ & $\begin{array}{c}0.044 \\
(0.010)\end{array}$ & $\begin{array}{r}-0.037 \\
0.266\end{array}$ & $\begin{array}{c}-0.026 \\
0.482\end{array}$ & $\begin{array}{c}-0.011 \\
0.749\end{array}$ \\
\hline Doesn’t search & $\begin{array}{c}0.005 \\
(0.002)\end{array}$ & $\begin{array}{c}0.004 \\
(0.003)\end{array}$ & $\begin{array}{c}0.006 \\
(0.003)\end{array}$ & $\begin{array}{c}0.004 \\
(0.003)\end{array}$ & $\begin{array}{l}0.000 \\
0.949\end{array}$ & $\begin{array}{l}0.002 \\
0.779\end{array}$ & $\begin{array}{c}-0.001 \\
0.839\end{array}$ \\
\hline Test of joint significance ( $\chi^{2}$ p-value) & & & & & 0.525 & 0.926 & 0.336 \\
\hline
\end{tabular}


Table C2: Potato Cultivation by Sample Farmers, 2008

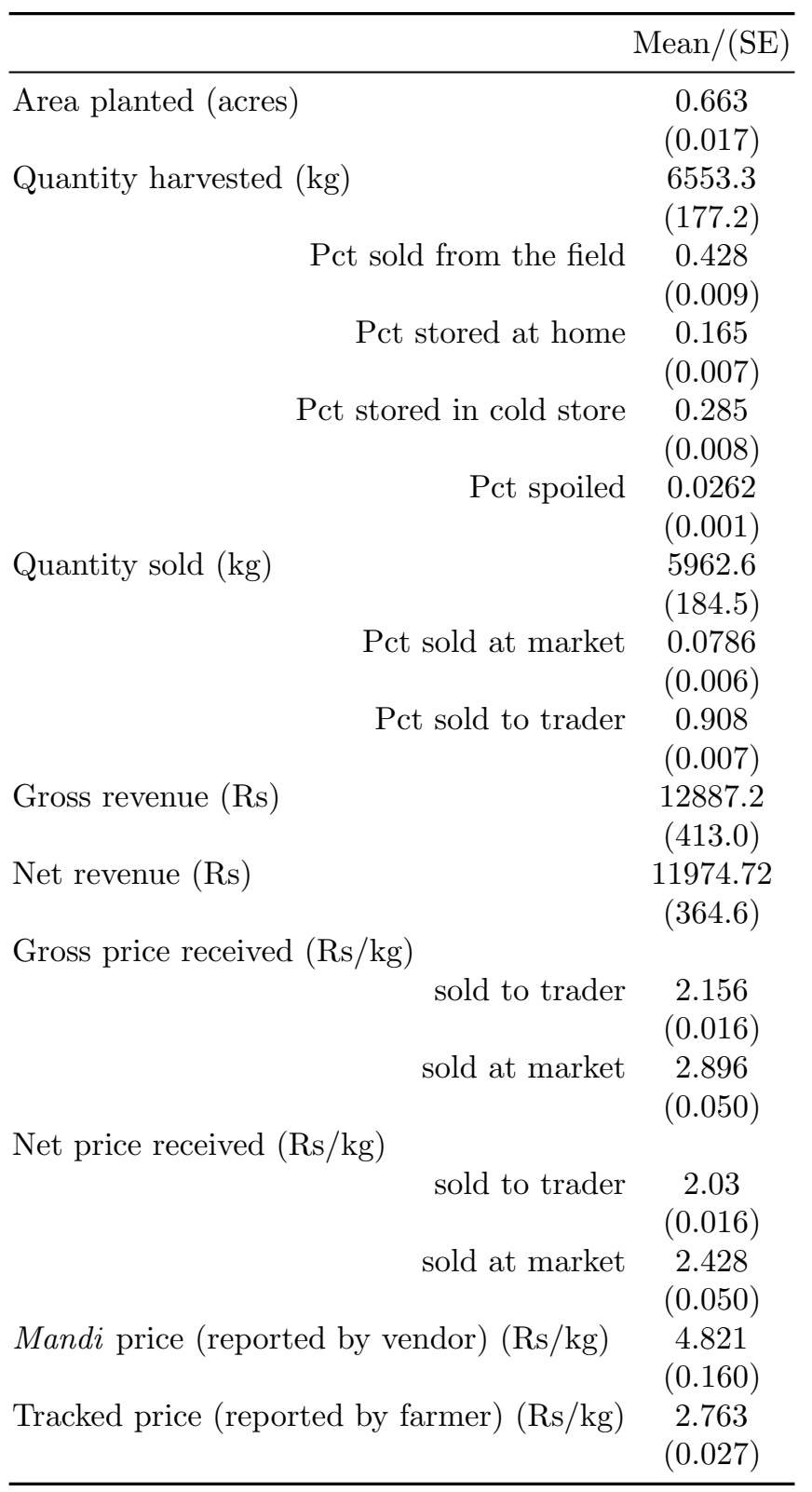




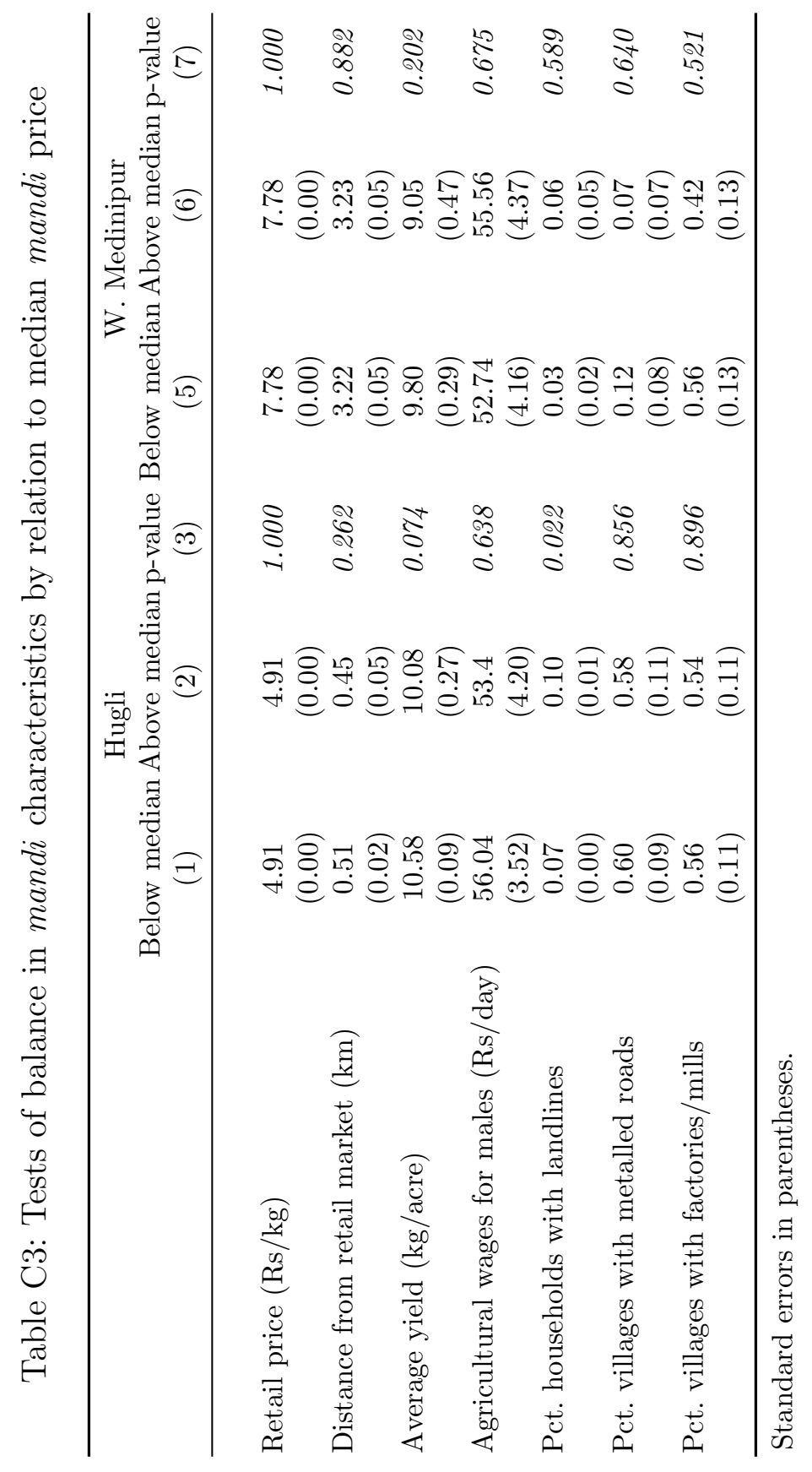




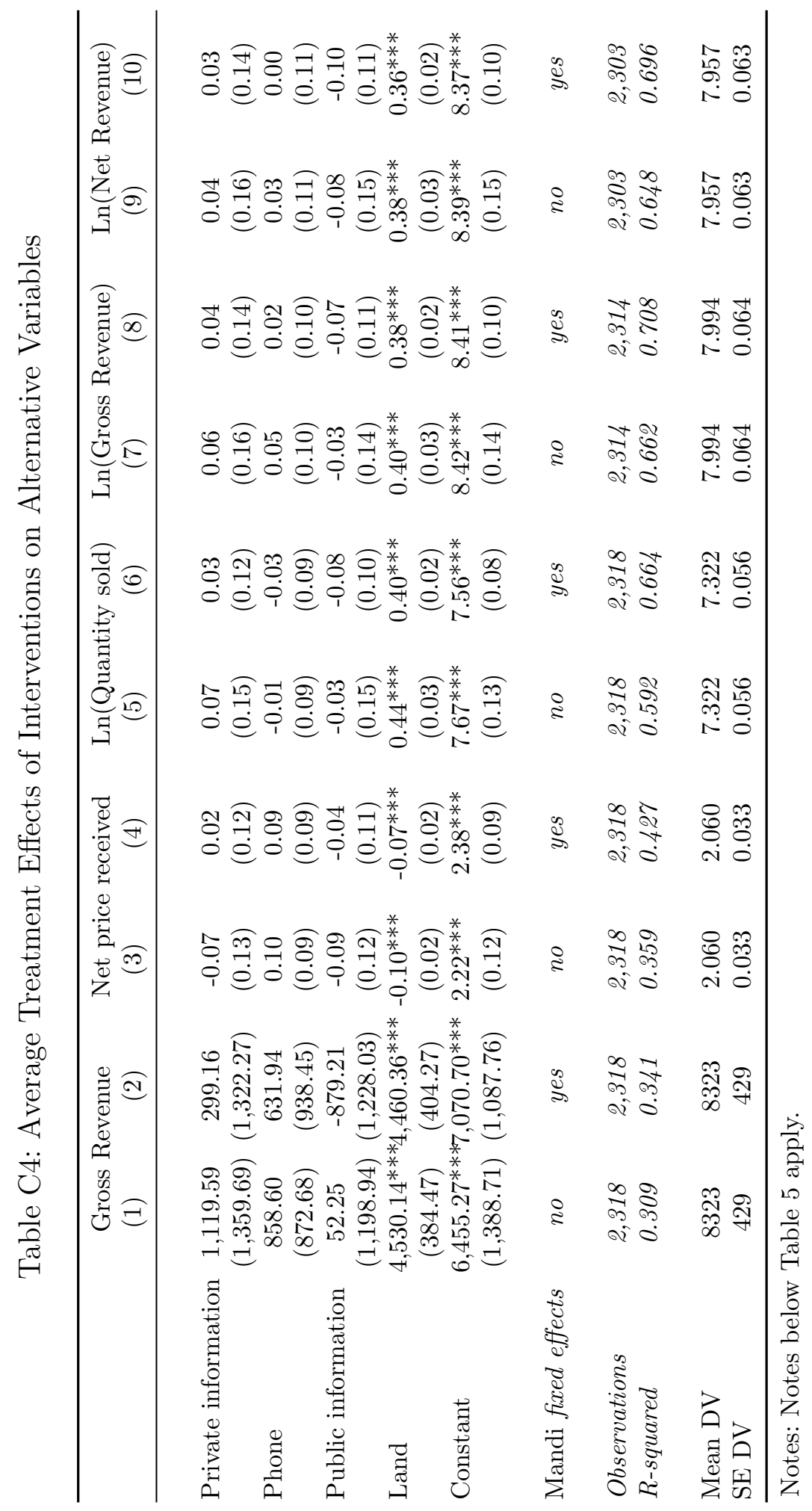


Table C5: Heterogeneous Treatment Effects of Interventions on Net Price Received

\begin{tabular}{|c|c|c|c|c|}
\hline & $\begin{array}{l}\text { Farmer- } \\
\text { specific } \\
\text { average } \\
(1)\end{array}$ & $\begin{array}{c}\text { Weighted } \\
\text { average } \\
\text { (2) }\end{array}$ & $\begin{array}{l}\text { Deviation } \\
\text { from } \\
\text { expected } \\
\text { mandi } \\
\text { price } \\
(3)\end{array}$ & $\begin{array}{l}\text { Long-term } \\
\text { relation- } \\
\text { ships } \\
\text { (4) }\end{array}$ \\
\hline Price regressor & $\begin{array}{c}0.2^{* *} \\
(0.1)\end{array}$ & & $\begin{array}{l}0.0^{*} \\
(0.0)\end{array}$ & $\begin{array}{c}0.3 \\
(0.2)\end{array}$ \\
\hline Private information & $\begin{array}{l}-0.6^{*} \\
(0.3)\end{array}$ & $\begin{array}{l}-0.6 \\
(0.4)\end{array}$ & $\begin{array}{c}0.1 \\
(0.1)\end{array}$ & $\begin{array}{c}0.4 \\
(0.7)\end{array}$ \\
\hline Private information $\times$ Price regressor & $\begin{array}{l}0.1^{*} \\
(0.1)\end{array}$ & $\begin{array}{c}0.2 \\
(0.1)\end{array}$ & $\begin{array}{c}0.2^{* * *} \\
(0.1)\end{array}$ & $\begin{array}{l}-0.1 \\
(0.2)\end{array}$ \\
\hline Phone & $\begin{array}{c}0.0 \\
(0.3)\end{array}$ & $\begin{array}{c}0.1 \\
(0.2)\end{array}$ & $\begin{array}{c}0.2 \\
(0.1)\end{array}$ & $\begin{array}{l}1.1 \\
(0.8)\end{array}$ \\
\hline Phone $\times$ Price regressor & $\begin{array}{c}0.0 \\
(0.1)\end{array}$ & $\begin{array}{l}-0.0 \\
(0.1)\end{array}$ & $\begin{array}{c}0.1 \\
(0.1)\end{array}$ & $\begin{array}{l}-0.3 \\
(0.2)\end{array}$ \\
\hline Public information & $\begin{array}{c}0.1 \\
(0.3)\end{array}$ & $\begin{array}{l}-0.1 \\
(0.4)\end{array}$ & $\begin{array}{l}-0.1 \\
(0.1)\end{array}$ & $\begin{array}{c}0.8 \\
(0.7)\end{array}$ \\
\hline Public information $\times$ Price regressor & $\begin{array}{l}-0.0 \\
(0.1)\end{array}$ & $\begin{array}{c}0.0 \\
(0.1)\end{array}$ & $\begin{array}{l}-0.0 \\
(0.0)\end{array}$ & $\begin{array}{l}-0.2 \\
(0.2)\end{array}$ \\
\hline Land & $\begin{array}{c}-0.1^{* * *} \\
(0.0)\end{array}$ & $\begin{array}{c}-0.1^{* * *} \\
(0.0)\end{array}$ & $\begin{array}{c}-0.1^{* * *} \\
(0.0)\end{array}$ & $\begin{array}{c}-0.1^{* *} \\
(0.0)\end{array}$ \\
\hline Constant & $\begin{array}{c}1.6^{* * *} \\
(0.3)\end{array}$ & $\begin{array}{c}2.4^{* * *} \\
(0.1)\end{array}$ & $\begin{array}{c}2.3^{* * *} \\
(0.1)\end{array}$ & $\begin{array}{l}1.3 \\
(0.9)\end{array}$ \\
\hline $\begin{array}{l}\text { Observations } \\
R \text {-squared }\end{array}$ & $\begin{array}{l}2,300 \\
0.453\end{array}$ & $\begin{array}{l}2,317 \\
0.432\end{array}$ & $\begin{array}{l}2,283 \\
0.384\end{array}$ & $\begin{array}{c}443 \\
0.535\end{array}$ \\
\hline $\begin{array}{l}\text { Mean DV } \\
\text { SE DV }\end{array}$ & $\begin{array}{c}2.054 \\
0.0329\end{array}$ & $\begin{array}{c}2.058 \\
0.0329\end{array}$ & $\begin{array}{c}2.206 \\
0.0206\end{array}$ & $\begin{array}{l}2.170 \\
0.112\end{array}$ \\
\hline
\end{tabular}

Notes: Notes below Table 6 apply. The dependent variable is the net price the farmer received from buyers over the year, computed by dividing net revenue by quantity. 
Table C6: Heterogeneous Impacts of Interventions on Gross Farm Revenue

\begin{tabular}{|c|c|c|c|c|}
\hline & $\begin{array}{c}\text { Farmer- } \\
\text { specific } \\
\text { average } \\
(1)\end{array}$ & $\begin{array}{c}\text { District } \\
\text { weights } \\
\\
(2)\end{array}$ & $\begin{array}{l}\text { Deviation } \\
\text { from } \\
\text { expected } \\
\text { mandi } \\
\text { price } \\
(3)\end{array}$ & $\begin{array}{l}\text { Long-term } \\
\text { relation- } \\
\text { ships } \\
\text { (4) }\end{array}$ \\
\hline Price regressor & $\begin{array}{c}694.9 \\
(530.3)\end{array}$ & & $\begin{array}{l}-385.8^{*} \\
(205.9)\end{array}$ & $\begin{array}{c}-407.9 \\
(1,089.3)\end{array}$ \\
\hline Private information & $\begin{array}{r}-8,716.1^{* *} \\
(3,546.0)\end{array}$ & $\begin{array}{c}-9,900.9^{* *} \\
(4,621.4)\end{array}$ & $\begin{array}{c}1,783.1 \\
(1,658.0)\end{array}$ & $\begin{array}{l}-10,641.0 \\
(6,706.7)\end{array}$ \\
\hline Private information $\times$ Price regressor & $\begin{array}{c}2,043.4^{* *} \\
(796.4)\end{array}$ & $\begin{array}{r}2,406.0^{* *} \\
(1,069.2)\end{array}$ & $\begin{array}{c}2,141.8^{* *} \\
(859.9)\end{array}$ & $\begin{array}{c}2,523.7 \\
(1,679.9)\end{array}$ \\
\hline Phone & $\begin{array}{c}4,505.0 \\
(3,698.1)\end{array}$ & $\begin{array}{c}1,381.6 \\
(3,557.1)\end{array}$ & $\begin{array}{c}481.6 \\
(1,333.0)\end{array}$ & $\begin{array}{c}8,929.4 \\
(7,128.6)\end{array}$ \\
\hline Phone $\times$ Price regressor & $\begin{array}{l}-938.6 \\
(863.3)\end{array}$ & $\begin{array}{l}-196.7 \\
(873.6)\end{array}$ & $\begin{array}{l}-419.8 \\
(834.6)\end{array}$ & $\begin{array}{l}-1,978.9 \\
(1,786.7)\end{array}$ \\
\hline Public information & $\begin{array}{r}-7,317.9^{* *} \\
(3,306.7)\end{array}$ & $\begin{array}{l}-8,033.0^{*} \\
(4,661.2)\end{array}$ & $\begin{array}{c}-708.9 \\
(1,262.6)\end{array}$ & $\begin{array}{c}-10,085.2^{*} \\
(5,949.7)\end{array}$ \\
\hline Public information $\times$ Price regressor & $\begin{array}{c}1,482.3^{* *} \\
(706.1)\end{array}$ & $\begin{array}{c}1,646.9 \\
(1,027.5)\end{array}$ & $\begin{array}{c}24.4 \\
(504.1)\end{array}$ & $\begin{array}{l}2,516.5^{*} \\
(1,445.5)\end{array}$ \\
\hline Land & $\begin{array}{c}4,387.5^{* * *} \\
(411.4)\end{array}$ & $\begin{array}{l}4,420.8^{* * *} \\
(402.2)\end{array}$ & $\begin{array}{l}4,570.9^{* * *} \\
(373.4)\end{array}$ & $\begin{array}{l}5,035.4^{* * *} \\
(858.2)\end{array}$ \\
\hline Constant & $\begin{array}{c}4,220.1 \\
(2,653.1)\end{array}$ & $\begin{array}{c}7,184.5^{* * *} \\
(1,026.1)\end{array}$ & $\begin{array}{c}7,194.1^{* * *} \\
(1,386.1)\end{array}$ & $\begin{array}{l}8,723.1^{*} \\
(4,704.8)\end{array}$ \\
\hline Observations & 2,300 & 2,317 & 2,283 & 443 \\
\hline$R$-squared & 0.350 & 0.345 & 0.317 & 0.460 \\
\hline $\begin{array}{l}\text { Mean DV } \\
\text { SE DV }\end{array}$ & $\begin{array}{l}8350 \\
432.3\end{array}$ & $\begin{array}{l}8327 \\
429.6\end{array}$ & $\begin{array}{l}10998 \\
346.4\end{array}$ & $\begin{array}{l}8762 \\
1026\end{array}$ \\
\hline
\end{tabular}

Notes: Notes below Table 6 apply. The dependent variable is the gross revenue the farmer received from buyers over the year. 
Table C7: Heterogeneous Impacts of Interventions on Ln(Quantity Sold)

\begin{tabular}{|c|c|c|c|c|}
\hline & $\begin{array}{c}\text { Farmer- } \\
\text { specific } \\
\text { average } \\
(1)\end{array}$ & $\begin{array}{c}\text { District } \\
\text { weights } \\
\\
(2)\end{array}$ & $\begin{array}{l}\text { Deviation } \\
\text { from } \\
\text { expected } \\
\text { mandi } \\
\text { price } \\
(3)\end{array}$ & $\begin{array}{l}\text { Long-term } \\
\text { relation- } \\
\text { ships } \\
\text { (4) }\end{array}$ \\
\hline Price regressor & $\begin{array}{l}-0.1 \\
(0.1)\end{array}$ & & $\begin{array}{c}-0.1^{*} \\
(0.0)\end{array}$ & $\begin{array}{l}-0.0 \\
(0.1)\end{array}$ \\
\hline Private information & $\begin{array}{c}-0.6^{*} \\
(0.3)\end{array}$ & $\begin{array}{l}-0.6 \\
(0.4)\end{array}$ & $\begin{array}{c}0.0 \\
(0.2)\end{array}$ & $\begin{array}{c}-1.3^{* *} \\
(0.6)\end{array}$ \\
\hline Private information $\times$ Price regressor & $\begin{array}{c}0.1^{* *} \\
(0.1)\end{array}$ & $\begin{array}{c}0.1 \\
(0.1)\end{array}$ & $\begin{array}{c}0.1 \\
(0.1)\end{array}$ & $\begin{array}{c}0.3^{* *} \\
(0.1)\end{array}$ \\
\hline Phone & $\begin{array}{c}0.2 \\
(0.4)\end{array}$ & $\begin{array}{l}-0.0 \\
(0.4)\end{array}$ & $\begin{array}{l}-0.1 \\
(0.1)\end{array}$ & $\begin{array}{c}0.4 \\
(0.7)\end{array}$ \\
\hline Phone $\times$ Price regressor & $\begin{array}{l}-0.1 \\
(0.1)\end{array}$ & $\begin{array}{l}-0.0 \\
(0.1)\end{array}$ & $\begin{array}{l}-0.1 \\
(0.1)\end{array}$ & $\begin{array}{l}-0.1 \\
(0.2)\end{array}$ \\
\hline Public information & $\begin{array}{c}-0.7^{* *} \\
(0.3)\end{array}$ & $\begin{array}{l}-0.6 \\
(0.4)\end{array}$ & $\begin{array}{l}-0.1 \\
(0.2)\end{array}$ & $\begin{array}{c}-1.8^{* * *} \\
(0.6)\end{array}$ \\
\hline Public information $\times$ Price regressor & $\begin{array}{c}0.1^{* *} \\
(0.1)\end{array}$ & $\begin{array}{c}0.1 \\
(0.1)\end{array}$ & $\begin{array}{c}0.1 \\
(0.1)\end{array}$ & $\begin{array}{c}0.4^{* * *} \\
(0.1)\end{array}$ \\
\hline Land & $\begin{array}{c}0.4^{* * *} \\
(0.0)\end{array}$ & $\begin{array}{c}0.4^{* * *} \\
(0.0)\end{array}$ & $\begin{array}{c}0.4^{* * * *} \\
(0.0)\end{array}$ & $\begin{array}{c}0.4^{* * * *} \\
(0.1)\end{array}$ \\
\hline Constant & $\begin{array}{c}8.0^{* * *} \\
(0.3)\end{array}$ & $\begin{array}{c}7.6^{* * *} \\
(0.1)\end{array}$ & $\begin{array}{c}7.7^{* * * *} \\
(0.1)\end{array}$ & $\begin{array}{c}8.0^{* * * *} \\
(0.4)\end{array}$ \\
\hline Observations & 2,300 & 2,317 & 2,283 & 443 \\
\hline$R$-squared & 0.668 & 0.665 & 0.600 & 0.705 \\
\hline Mean DV & 7.323 & 7.322 & 7.657 & 7.578 \\
\hline SE DV & 0.057 & 0.056 & 0.038 & 0.125 \\
\hline
\end{tabular}

Notes: Notes below Table 6 apply. The dependent variable is the logarithm of the quantity of potatoes the farmer sold over the year. 
Table C8: Heterogeneous Treatment Effects of Interventions on Ln(Gross Farmer Revenue)

\begin{tabular}{|c|c|c|c|c|}
\hline & $\begin{array}{c}\text { Farmer- } \\
\text { specific } \\
\text { average } \\
(1)\end{array}$ & $\begin{array}{c}\text { District } \\
\text { weights } \\
\\
(2)\end{array}$ & $\begin{array}{l}\text { Deviation } \\
\text { from } \\
\text { expected } \\
\text { mandi } \\
\text { price } \\
(3)\end{array}$ & $\begin{array}{l}\text { Long-term } \\
\text { relation- } \\
\text { ships } \\
\text { (4) }\end{array}$ \\
\hline Price regressor & $\begin{array}{l}-0.0 \\
(0.1)\end{array}$ & & $\begin{array}{l}-0.0 \\
(0.0)\end{array}$ & $\begin{array}{c}0.1 \\
(0.2)\end{array}$ \\
\hline Private information & $\begin{array}{c}-0.9^{* *} \\
(0.4)\end{array}$ & $\begin{array}{l}-1.1^{* *} \\
(0.5)\end{array}$ & $\begin{array}{c}0.1 \\
(0.2)\end{array}$ & $\begin{array}{l}-1.2 \\
(0.7)\end{array}$ \\
\hline Private information $\times$ Price regressor & $\begin{array}{c}0.2^{* * *} \\
(0.1)\end{array}$ & $\begin{array}{c}0.3^{* *} \\
(0.1)\end{array}$ & $\begin{array}{c}0.1 \\
(0.1)\end{array}$ & $\begin{array}{l}0.3^{*} \\
(0.2)\end{array}$ \\
\hline Phone & $\begin{array}{c}0.4 \\
(0.4)\end{array}$ & $\begin{array}{c}0.2 \\
(0.4)\end{array}$ & $\begin{array}{l}-0.0 \\
(0.1)\end{array}$ & $\begin{array}{l}1.3^{* *} \\
(0.6)\end{array}$ \\
\hline Phone $\times$ Price regressor & $\begin{array}{l}-0.1 \\
(0.1)\end{array}$ & $\begin{array}{l}-0.0 \\
(0.1)\end{array}$ & $\begin{array}{l}-0.1 \\
(0.1)\end{array}$ & $\begin{array}{c}-0.3^{* *} \\
(0.1)\end{array}$ \\
\hline Public information & $\begin{array}{c}-0.8^{* *} \\
(0.3)\end{array}$ & $\begin{array}{l}-0.9^{*} \\
(0.5)\end{array}$ & $\begin{array}{l}-0.1 \\
(0.2)\end{array}$ & $\begin{array}{l}-1.3^{*} \\
(0.7)\end{array}$ \\
\hline Public information $\times$ Price regressor & $\begin{array}{c}0.2^{* *} \\
(0.1)\end{array}$ & $\begin{array}{c}0.2^{*} \\
(0.1)\end{array}$ & $\begin{array}{c}0.0 \\
(0.1)\end{array}$ & $\begin{array}{l}0.3^{*} \\
(0.2)\end{array}$ \\
\hline Land & $\begin{array}{c}0.4^{* * *} \\
(0.0)\end{array}$ & $\begin{array}{c}0.4^{* * *} \\
(0.0)\end{array}$ & $\begin{array}{c}0.4^{* * *} \\
(0.0)\end{array}$ & $\begin{array}{c}0.4^{* * *} \\
(0.1)\end{array}$ \\
\hline Constant & $\begin{array}{c}8.5^{* * *} \\
(0.3)\end{array}$ & $\begin{array}{c}8.4^{* * *} \\
(0.1)\end{array}$ & $\begin{array}{c}8.5^{* * *} \\
(0.1)\end{array}$ & $\begin{array}{c}8.4^{* * *} \\
(0.7)\end{array}$ \\
\hline $\begin{array}{l}\text { Observations } \\
R \text {-squared }\end{array}$ & $\begin{array}{l}2,297 \\
0.713\end{array}$ & $\begin{array}{l}2,313 \\
0.711\end{array}$ & $\begin{array}{l}2,280 \\
0.666\end{array}$ & $\begin{array}{l}441 \\
0.758\end{array}$ \\
\hline $\begin{array}{l}\text { Mean DV } \\
\text { SE DV }\end{array}$ & $\begin{array}{l}7.993 \\
0.064\end{array}$ & $\begin{array}{l}7.994 \\
0.064\end{array}$ & $\begin{array}{l}8.428 \\
0.040\end{array}$ & $\begin{array}{l}8.256 \\
0.153\end{array}$ \\
\hline
\end{tabular}

Notes: Notes below Table 6 apply. The dependent variable is the logarithm of the gross revenue the farmer received over the year. 
Table C9: Heterogeneous Treatment Effects of Interventions on Ln(Net Farmer Revenue)

\begin{tabular}{|c|c|c|c|c|}
\hline & $\begin{array}{c}\text { Farmer- } \\
\text { specific } \\
\text { average } \\
\text { (1) }\end{array}$ & $\begin{array}{c}\text { District } \\
\text { weights } \\
\\
\\
(2)\end{array}$ & $\begin{array}{l}\text { Deviation } \\
\text { from } \\
\text { expected } \\
\text { mandi } \\
\text { price } \\
(3)\end{array}$ & $\begin{array}{l}\text { Long-term } \\
\text { relation- } \\
\text { ships } \\
\text { (4) }\end{array}$ \\
\hline Price regressor & $\begin{array}{l}-0.0 \\
(0.1)\end{array}$ & & $\begin{array}{c}-0.1 \\
(0.0)\end{array}$ & $\begin{array}{c}0.1 \\
(0.2)\end{array}$ \\
\hline Private information & $\begin{array}{c}-1.0^{* *} \\
(0.4)\end{array}$ & $\begin{array}{c}-1.1^{* *} \\
(0.5)\end{array}$ & $\begin{array}{c}0.0 \\
(0.2)\end{array}$ & $\begin{array}{l}-1.0 \\
(0.8)\end{array}$ \\
\hline Private information $\times$ Price regressor & $\begin{array}{c}0.2^{* * *} \\
(0.1)\end{array}$ & $\begin{array}{c}0.3^{* *} \\
(0.1)\end{array}$ & $\begin{array}{c}0.1 \\
(0.1)\end{array}$ & $\begin{array}{c}0.2 \\
(0.2)\end{array}$ \\
\hline Phone & $\begin{array}{c}0.4 \\
(0.4)\end{array}$ & $\begin{array}{c}0.2 \\
(0.4)\end{array}$ & $\begin{array}{c}0.0 \\
(0.2)\end{array}$ & $\begin{array}{c}1.7^{* *} \\
(0.6)\end{array}$ \\
\hline Phone $\times$ Price regressor & $\begin{array}{l}-0.1 \\
(0.1)\end{array}$ & $\begin{array}{c}-0.0 \\
(0.1)\end{array}$ & $\begin{array}{l}-0.0 \\
(0.1)\end{array}$ & $\begin{array}{c}-0.4^{* *} \\
(0.2)\end{array}$ \\
\hline Public information & $\begin{array}{c}-0.8^{* *} \\
(0.3)\end{array}$ & $\begin{array}{c}-0.9^{*} \\
(0.5)\end{array}$ & $\begin{array}{l}-0.1 \\
(0.2)\end{array}$ & $\begin{array}{c}-1.2 \\
(0.8)\end{array}$ \\
\hline Public information $\times$ Price regressor & $\begin{array}{c}0.2^{* *} \\
(0.1)\end{array}$ & $\begin{array}{l}0.2^{*} \\
(0.1)\end{array}$ & $\begin{array}{c}0.0 \\
(0.1)\end{array}$ & $\begin{array}{c}0.2 \\
(0.2)\end{array}$ \\
\hline Land & $\begin{array}{c}0.4^{* * *} \\
(0.0)\end{array}$ & $\begin{array}{c}0.4^{* * *} \\
(0.0)\end{array}$ & $\begin{array}{c}0.4^{* * *} \\
(0.0)\end{array}$ & $\begin{array}{c}0.4^{* * *} \\
(0.1)\end{array}$ \\
\hline Constant & $\begin{array}{c}8.5^{* * *} \\
(0.3)\end{array}$ & $\begin{array}{c}8.4^{* * *} \\
(0.1)\end{array}$ & $\begin{array}{c}8.4^{* * *} \\
(0.1)\end{array}$ & $\begin{array}{c}8.3^{* * *} \\
(0.8)\end{array}$ \\
\hline Observations & 2,286 & 2,302 & 2,269 & 437 \\
\hline$R$-squared & 0.701 & 0.699 & 0.652 & 0.730 \\
\hline Mean DV & 7.96 & 7.96 & 8.38 & 8.25 \\
\hline SE DV & 0.06 & 0.06 & 0.04 & 0.16 \\
\hline
\end{tabular}

Notes: Notes below Table 6 apply. The dependent variable is the logarithm of the net revenue the farmer received over the year. 


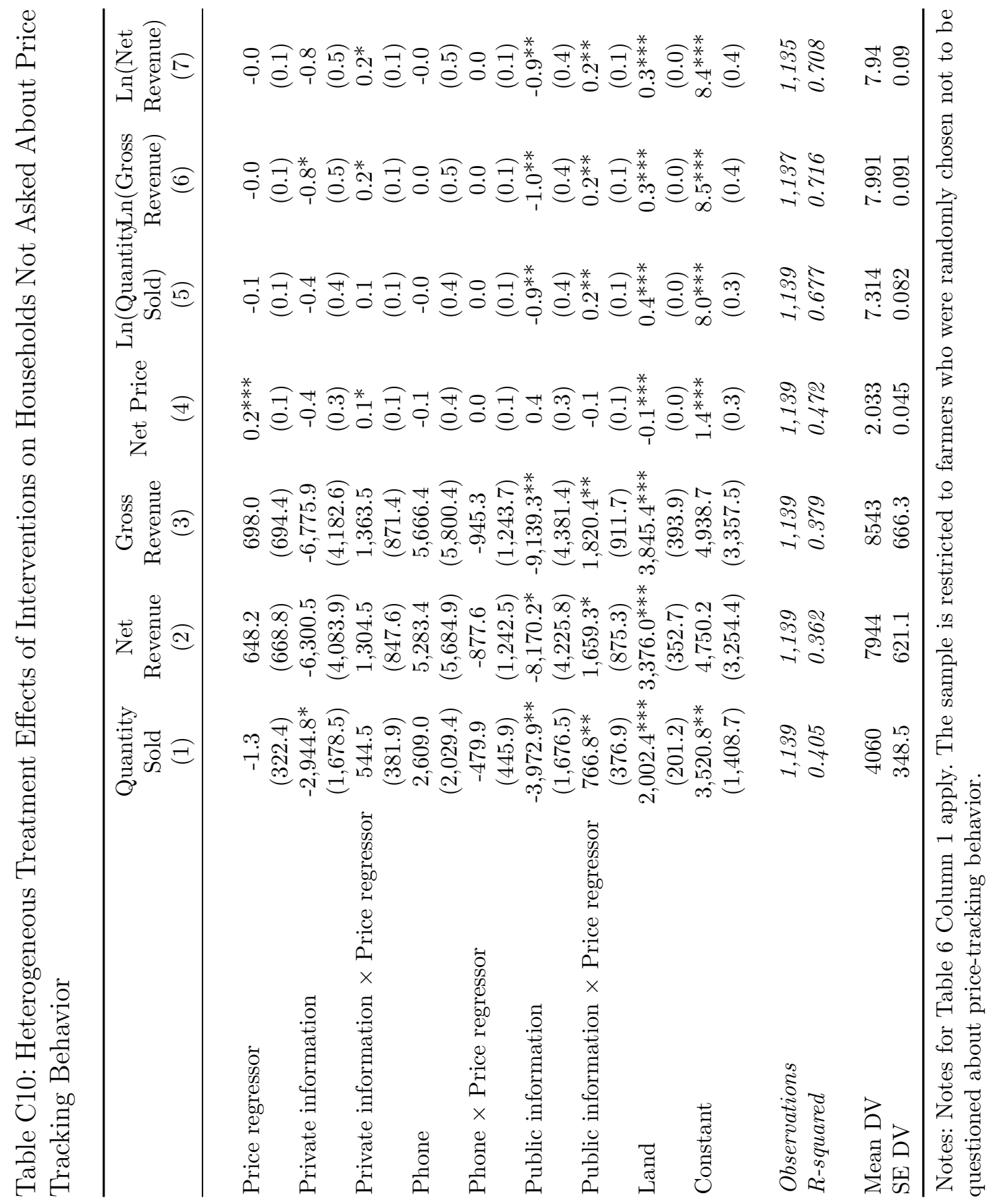

